\title{
Kent Dokusu Morfolojik Değişiminin Fraktal Geometri Aracılığıyla Hesaplanması: Bursa Örneği
}

\author{
Ceyda ILLHAN ${ }^{1 \star}$, Özgür EDIZ ${ }^{2}$
}

Öz

Kentsel doku morfolojisi planlama süreci M.Ö.7. yüzyıla dayanan ve hala tartışılan çok boyutlu ve disiplinlerarası bir konudur. Geleneksel yöntemlerle yapılan çalışmalar ve sınıflandırmalar, çok hızlı değişip dönüşen çağımız kentlerini anlayabilme konusunda yetersiz kalmaktadır. Bu sebeple, geleneksel Öklid geometrisiyle ölçülemeyen doğa ve onun karmaşık yapısını anlayabilmek için ortaya atılan Kaos Teorisi ve fraktal geometri, son yıllarda kent morfolojisi çalışmalarında da kullanılmaya başlanmıştır. Bu çalışmadaki temel amaç; bir kentin oluşum ve gelişim süreçlerini, oldukça zengin bir tarihi geçmişe sahip olan Bursa kentinin morfolojik değişimi üzerinden, kentsel ve bölgesel ölçeklerde yapılan fraktal analizlerle araştırmak; bütüncül bir yaklaşımla ele alınan kent bileşenlerinin zamansal ve mekansal değişimini, somut sayısal veriler üzerinden okumaktır. İlk bölümde yedi farklı yıla ait Bursa kent lekesi analiz edilirken; ikinci bölümde kentin farklı konumlarında, farklı dönemlerde oluşmuş ve son 15 yıl içinde en çok değişim gösteren bölgelerinden seçilen dokuz alanın geçmiş ve günümüz dokularının fraktalitesi ölçülmüştür. Araştırma sonucunda, yeni oluşan kent dokusunun mevcut olana 'eklenme' veya 'eklemlenme' yoluyla geliştiği ve kentsel alt bölgelerdeki doku gelişim sürecinin, kent genelinin büyüme sürecine sayısal verilerle kanıtlanan bir benzerlik gösterdiği tespit edilmiştir. Kaotik morfolojik süreçteki düzeni ortaya koyması açısından çarpıcı veriler sunan çalışmada; kentin kendi kendini organize ederek büyüyen çoklu-fraktal bir yapı olduğu anlaşılmıştır.

Anahtar Kelimeler: Kent morfolojisi, Kentsel doku, Fraktal geometri, Bursa.

\section{Fractal Geometry Analysis of Urban Tissue Morphological Change: The Case Study of Bursa}

\begin{abstract}
\footnotetext{
${ }^{1}$ Uludağ Üniversitesi, Fen Bilimleri Enstitüsü, Bina Bilgisi Bilim Dalı, Yüksek Lisans Öğrencisi

${ }^{2}$ Prof. Dr., Uludağ Üniversitesi, Mimarlık Fakültesi, Mimarlık Bölümü, Bursa, Türkiye

*Illgili yazar/ Corresponding author: ceydailhn@gmail.com

Gönderim Tarihi: 29.03.2019

Kabul Tarihi: 29.06.2019
}

The urban tissue morphology planning process is a multidimensional and interdisciplinary subject, which dates back to the $7^{\text {th }}$ century BC and is still debated. Studies and classifications carried out with traditional methods are insufficient to understand the cities of our age which have changed very rapidly. For this reason, Chaos Theory and fractal geometry, which have been put forward to understand the nature and its complex structure which cannot be measured by traditional Euclidean geometry, have been used in urban morphology studies in recent years. The main purpose of this study is; to investigate the formation and development processes of a city through the morphological change of the city of Bursa, which has a very rich historical background, by using fractal analysis in urban and regional scales; and to examine the temporal and spatial changes of urban components which are handled with a holistic approach, on concrete numerical data. In the first part, Bursa city stains 
of seven different years were analyzed; In the second section, the fractal of the past and present tissues of nine different areas of the city, which were chosen from different regions and which were the most changed in the last 15 years, were measured. As a result of the research, it has been determined that the newly formed urban tissue developed by 'addition' or 'articulation' to the existing ones; and that the tissue development process in urban sub-regions and the growth process of the city, shows a similarity with the numerical data. In the study which presents important data in terms of revealing the order in chaotic morphological process; the city was understood to be a self-organizing multi-fractal structure.

Keywors: Kent morfolojisi, Kentsel doku, Fraktal geometri, Bursa.

\section{GíRiş}

Kent dokusu, tarih boyunca kent sakinleri, yöneticiler, vakıflar, belediyeler, sivil toplum kuruluşları, mimarlar ve kent plancıları gibi çok çeşitli aktörlerin ve pek çok etmenin yönlendiriciliği altında oluşan, çok katmanlı, anlaşııması güç bir yapıdır. Küreselleşen dünyada hızla büyüyüp metropolleşen kentlerde artan karmaşıklık, kent morfolojisini anlamaya yönelik çalışmaları ve hızlı kentleşme sorunlarına çözüm arayışlarını da beraberinde getirmiştir. Doğru ve yerinde müdahaleler yapabilmek, ancak kentlilerin intiyaç ve talepleri ile kent dokusunun morfolojik eğilimlerini doğru analiz edebilmekten geçmektedir.

Morfoloji, Yunanca 'morphe' ve 'logos' köklerinden gelen, şekil, biçim bilimi anlamına gelmektedir. Şekil kelimesi "bir nesnenin dış çizgileri bakımından niteliği, dıştan görünüş biçimi olarak tanımlanmaktadır." (Türkçe Sözlük 1985, Url1) Kent morfolojisi; yerleşimlerin formunu, oluşum ve dönüşüm süreçlerini, mekansal karakterini, tarihsel gelişim süreçleriyle ve yerleşimleri oluşturan bileşen parçalarını çeşitli analizlerle anlamayı sağlayan bir yaklaşımdır. (Kubat ve Topçu, 2009, s.336) Kentsel morfoloji bileşenleri genel olarak; açık yeşil alanlar, yapılar, sokak örüntüsü, parseller ve arazi kullanımı ile bunların alt bileşenleri olarak açıklanmıştır (Yaygın, 2016, s.28). 20.yy itibariyle bir bilim dalı olarak tartışılagelen kent morfolojisi ve planlama ilkeleri, yasa ve yönetmeliklerle olabildiğince kontrol edilmeye çalışılmış; sanayileşme, kentsel eşikler, kuşak alanlar, nüfus artışı, kentleşme ve kentlileşme, kent kimliği, tipolojik farklılaşma, koruma kavramı, eskime, kentsel dönüşüm, enerji yönetimi, sürdürülebilirlik gibi konularla ilişkilendirilip ele alınarak kentsel gelişimin doğasını anlamak ve gelişim sürecini yönetebilmek amacıyla çalışmalar yapılmıştır.

Yapılan araştırmalara bakıldığında fiziksel kent dokusunun oluşum ve büyümesinin belirleyicileri; doğal, sosyo-kültürel, ekonomik etmenler, afetler, ulaşım olanakları, göç ve demografik değişim, siyasi yönetim şekli ve kentsel kararlar, yeni çekim alanlarının oluşturulması (kentsel odaklar), kentsel dönüşümler ve kentin gelişim potansiyeli olarak sayılabilmektedir. Ne var ki her kentin yönlendirici değişkenleri ve etki oranları birbirinden farklı olmakla birlikte; aynı kent için bile farklı zamanlarda farklı değişkenler daha baskın etkiler gösterebilir. Hatta bir zamanlar ilerleme olarak görülen otomobil sahipliliği gibi güçlerin 21.yyda kirlilik, saçılma, arazi kayıpları gibi çözülmesi gereken problemlere neden olduğunun farkına varılmıştır (Mcadams, 2007, s.152). Bu açıdan geleneksel yöntemlerle, iç içe geçmiş kent bileşenlerini ayrı ayrı değerlendirmek; ya da kentsel dokuyu biçimine göre kategorize etmek yerine; kenti farklı dinamikleriyle bir bütün olarak okumak gerekmektedir. 
1963 yilında Massachussets Institude of Technology (MIT)'den Edward Lorenz tarafından ortaya konan Kaos teorisi, meteoroloji, matematik, fizik, ekonomi, tıp, mimarlık, şehir planlama ve kentsel coğrafya dahil pek çok disiplinde yeni ufuklar açmıştır. Teoriye göre kaotik sistemlerde; bir bütünü oluşturan parçalar bütüne dair ipuçları barındırır; düzensizliğin içinde gizli bir düzen (order of disorder) vardır; 'kelebek etkisi' olarak nitelendirilen başlangıç koşullarına hassas bağlılık ve 'garip çekerler' (strange attractors) denilen güçlü odak noktaları bulunur (Oestreicher, 2007, s.283; Kaya, 2010, s.44).

Pek çok matematikçinin üretimlerinden de yararlanarak, 1976'da matematikçi Benedikt Mandelbrot tarafından, şekil ve sınırları belli öklidyen geometriye karşılık öne sürülen fraktal geometri, Kaos Teorisini somutlaştıran alternatif bir matematiksel kurgu olarak karşımıza çıkmaktadır. Fraktal kavramı, 'parçalı, kırıklı' anlamlarına gelen Latince 'fraktus' kelimesinden türemiştir. Fraktaller, benzer formların ölçekten bağımsız farklı gözlem seviyelerinde tekrarlanması olarak tanımlanabilen kendine benzerlik (selfsimilarity) ve 1 ile 2 arasında ölçülen fraktal boyut (fractal dimension) olmak üzere iki temel özelliğe sahiptir (Oestreicher, 2007, s.285).

Doğada dağlar, denizler, kıyı şeridi, bulutlar, ağaçlar ve tüm varlıklarda; şimşek, kasırga, deprem gibi meteorolojik olayların gerçekleşme döngüsünde; ekonomi tahminlerinde; canlıların yaşam döngüsünde; bir hücrenin mutasyonunda; kısacası içinde 'rastgelelik' barındırdığı düşünülen her olguda kaos teorisi ve fraktal geometrinin varlığından bahsetmek mümkündür. Michael Batty, 1996'da yazdığı 'Fraktal Cities' kitabında, kentlerde de fraktal analizin kullanılabileceği fikrini ortaya atmıştır (Mcadams, 2007, s.151).

Bu yöntemle kentlere dair yapılan çalışmalar incelendiğinde yerleşimlerin fraktal analiz yoluyla mekansal olarak karşılaştırılması (Mcadams, 2007; Kaya, 2010; Lagarias, 2007; Kaya ve Bölen, 2011; Arrouf ve diğ.,2015), zamansal morfolojik değişimin yorumlanması (Tannier ve Pumain, 2005; Caglioni ve Giovanni, 2006; Kaya, 2010), mimarlık, kent ve doğa benzeşimleri (Josephine ve Ostwald, 2009) yada tarihi yapıların plan, cephe sistemlerinin karşılaştırılması (Ostwald ve Ediz, 2014, s.n.y.) gibi var olan dokuların analizleri yapılabileceği gibi; mimari doku üretme sürecinde de deneysel çalışmalar yapıldığı görülmüştür (Ediz, 2003; Gözübüyük, 2007). Tasarım aşamasında var olan yapılı veya doğal çevrenin fraktalitesi tanımlanarak bu değere yakın değerlerde, çevre ile uyumlu yeni yapılaşma varyasyonları bilgisayar ortamında üretilebilmektedir. Bu açıdan fraktal analiz tasarıma yardımcı bir araç olarak da kullanılabilmektedir.

Tüm çalışmalar ışığında, "Kentsel dokular, fraktal özellikler gösteren kaotik ve dinamik sistemlerdir." hipotezi üzerine temellendirilen bu araştırmada, 2014 yılında altı alanıyla Unesco miras listesine giren Bursa kentinin morfolojik değişimi fraktal yöntemle analiz edilecektir. Çalışmada cevap aranan temel sorular şunlardır;

- Kentsel doku morfolojisi nasıl oluşur ve gelişir?

- Bir kent dokusunun farklı dönemlerde oluşmuş, farklı ölçeklerdeki alt alanları birbirleriyle veya kent geneliyle benzer özellikler göstermekte midir?

Çalışmanın alt soruları ise Bursa örneklemi üzerinden şu şekilde belirlenmiştir;

- Bursa kentinin oluşum ve gelişimini etkileyen etmenler ve kırılma noktaları nelerdir? 
- Analiz verileri doğrultusunda Bursa kent dokusu zamansal (geçmişten günümüze) ya da mekansal (merkezden çeperlere) ne gibi farklılıklar veya benzerlikler göstermektedir?

$\mathrm{Bu}$ bağlamda ön bilgi olarak fraktal analiz yönteminin tanıtılmasının ardından Bursa kentinin oluşumu ve kısaca kent tarihinden bahsedilecektir. Son bölümde Bursa dokusu, kentsel ve bölgesel ölçeklerde, bütüncül bir yaklaşımla analiz edilecek, veriler karşılaştırmalı olarak değerlendirilecektir.

\section{FRAKTAL ANALIZ YÖNTEMI}

\subsection{Fraktalitenin Ölçümü: Kutu Sayım Yöntemi}

Fraktal boyut pürüzlülük derecesinin ifadesidir, yani bir nesnenin ne kadar dokuya sahip olduğu anlamına gelir (Bovill,1996, s.118). Bu çalışmada, kendine benzerlik seviyesi tüm ölçeklerde aynı olmayan kompleks dokuların fraktal analizinde en çok kullanılan yöntem olan kutu sayımı (box counting) yönteminden yararlanılacaktır. Yöntemde, doluluk ve boşlukların temsil edildiği ölçümü yapılacak ikili görüntü, her çevrimde (iteration) farklı kutu boyutlarına sahip bir ızgarayla çakıştırıır. İçinde veri bulunan 'dolu kutu sayısı' ve yerleştirilen ızgaranın alt satırındaki kutu sayısının tersiyle ifade edilen 'kutu boyutu' değişimlerinin logaritmik oranı (log-log diyagramındaki ortalama eğim) fraktal boyutu vermektedir. (Ediz ve Ostwald, 2012, s.175) (Şekil 1)

$$
D_{B(1-2)}=\left[\log \left(N_{(S 2)}\right)-\log \left(N_{(S 1)}\right)\right] /\left[\log \left(1 / S_{2}\right)-\log \left(1 / S_{1}\right)\right]
$$

Bu denklemde;

$D_{B}$ : Kutu sayım yöntemine göre fraktal boyut

$\mathrm{N}_{(\mathrm{S} 2)}$ : Sonraki çevrimdeki dolu kutu sayısı, $\mathrm{N}_{(\mathrm{S} 1)}$ : Önceki çevrimdeki dolu kutu sayısı

$1 / S_{2}$ : Sonraki çevrimdeki kutu boyutu, $1 / S_{2}$ : Önceki çevrimdeki kutu boyutudur.
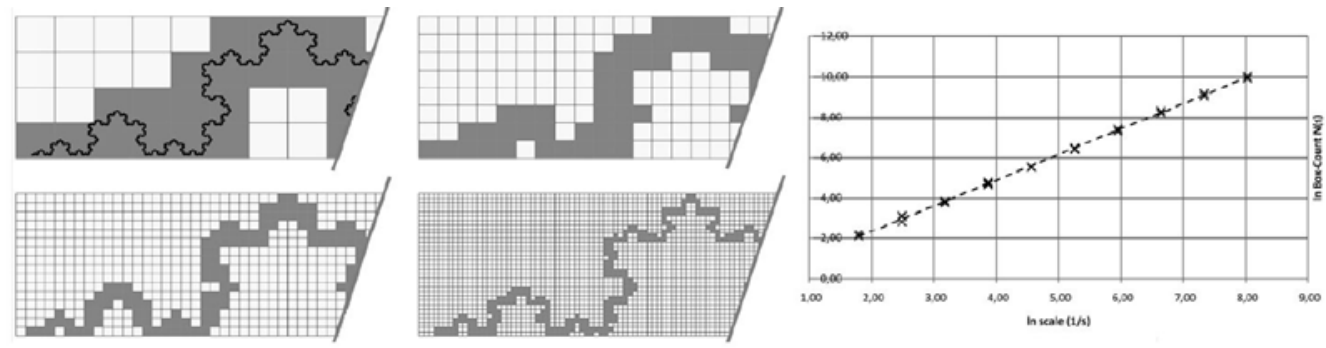

Şekil 1: Koch eğrisinin kutu sayım görseli ve logaritmik eğri grafiği. (Lorenz, 2009, s.3)

Detay zenginliği fazla olan dokuların kesirli fraktal boyutu 2'ye yakınken; detay zenginliği azaldıkça boyut 1'e yani Öklid geometrisine yaklaşacaktır. Modernist, minimalist, pürist yaklaşımlarda bu değer sadeliği kanıtlarcasına 1 çıkmaktadır. (Ediz, 2003, s.84-85)

\subsection{Gözeneklilik Analizi}

Kentsel doluluk patternini ölçen fraktal boyutun tamamlayıcı ve karşıt ölçümü olarak gözeneklilik (lacunarity), kentsel boşlukların fiziksel dağılımının sayısal değeridir. Fraktal boyutları birbirine çok yakın ve hatta aynı olan iki farklı yerleşim dokusu, gözeneklilik değerine göre ayırt edilebilir. (Şekil 2) Boşlukların dağılımındaki heterojenlik ve boşluk büyüklüğü arttıkça gözeneklilik değeri artar. (Kaya, 2010, s.33) 


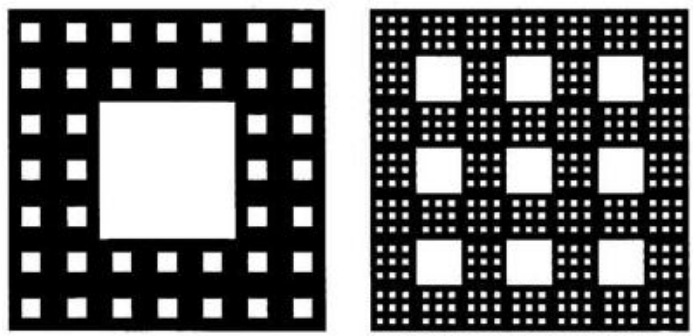

Şekil 2: Fraktal boyutu aynı, gözenekliliği farkı ‘Sierpinski halısı’ yapay fraktal örneği.

(Mandelbrot,1977; s.318)

Fraktal ve gözeneklilik analizlerinde Image-J programının FracLac eklentisinden yararlanılmıştır. FracLac'ın avantajı farklı kutu boyutları ve kutu konumları için en doğru ve pratik şekilde maksimum, minimum ve ortalama boyut ölçümü yapabilmesidir.

\section{BURSA KENTI OLUŞUM VE GELIŞiMi}

Marmara bölgesinin güneydoğusunda bulunan Bursa, kuzeyinde Marmara Denizi ve Yalova, kuzeydoğusunda Kocaeli ve Sakarya, doğusunda Bilecik, güneyinde Kütahya ve Balıkesir ile çevrilidir. (Şekil 3) Uludağ'ın kuzeybatı eteklerinde kurularak doğu-batıkuzey yönünde gelişen kent verimli ovaları, su kaynakları, İstanbul'a ve uluslararası ticaret yollarına yakın konumu sayesinde tarih boyunca önemli bir ticari merkez olmuştur. (Tekeli, 1999, s.8)
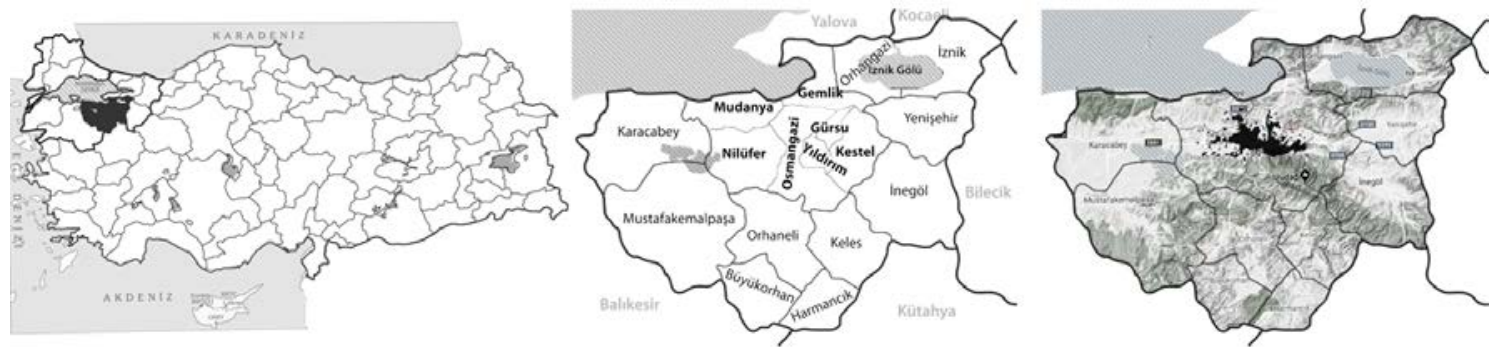

Şekil 3: Bursa kentinin yeri, ilçeleri, topoğrafyası ve kentsel dokunun konumu.

Bulunan höyükler ve kalıntılar 7000 yıldır Bursa ve çevresinin yerleşim bölgesi olduğunu göstermektedir. MÖ.185 yılında bugünkü Hisar bölgesinde surlarla çevrili bir tepe üzerinde Prusias ad Olympum (Uludağ'ın Bursa'sı) adıyla kurulmuş olan kent; MÖ.74 yılında Roma İmparatorluğu'na katılmış; MS.395'te Bizans'a geçen Prusa kentinde kaplıcalar ünlenmiş, 552 yılında Çin'den getirilen ipekböceği tohumlarıyla ipek üretimine başlanmıştır. (Tekeli, 1999, s.10)

1326 yılında Osmanlı tarafından alınarak devletin ilk başkenti yapılan Bursa, 800m'ye $500 \mathrm{~m}$ büyüklüğündeki kale içindeki yerleşimden ve taht-ı kale (kale altı) denilen yerde iki rum, bir yahudi mahallesinden ibarettir. İlk olarak 1340'larda Orhan Gazi'nin sur dışında Hisar'ın doğusunda yaptırdığı cami, medrese, imaret ve bedestenden oluşan külliye bugün hala kentin ana merkezi olan Hanlar Bölgesi'nin çekirdeğini oluşturmaktadır. I.Murat'ın Çekirge'de(1370), Yıldııım Beyazid'in Yıldırım'da (1390), Çelebi Mehmet'in Yeşil'de(1420), II.Murat'ın Muradiye'de(1440) yaptırdığı külliyeler ve çevrelerinde kendiliğinden oluşan, farklı etnik gruplara ait mahalleler Bursa'nın tarihi organik kent dokusunu oluşturmuştur (Tekeli, 1999, s.14-15; Kaplanoğlu, 2008, s.40). Büyük yangınlarla ve depremlerle defalarca tahribata uğrayan kent dokusunda 1855 
depremi sonrasında yeniden yapılandırılma intiyacı ile 1862'de Suphi Bey önderliğinde kapsamlı bir halihazır kent haritası çizilmiştir. (Şekil 4)

Bursa'nın yaşadığı ilk büyük kırılma 14.yy’da kale dışında bedesten merkezli çarşı sisteminin oluşmasıyken; ikincisi 19.yy'ın ikinci yarısında Osmanlı modernleşmesi sürecinde kentin dönüşümüdür. (Tekeli, 1999, s.7) 17.yy'dan itibaren iç karışıklıkların da etkisiyle durağan bir sürece giren Bursa'da 19.yy’a kadar küçük ölçekli ipek imalatı, teknolojik gerilik, maliyet ve kalitede Avrupa'nın gerisinde kalma, İpek yolu güzergahının değişmesi gibi etmenler köklü değişiklikleri gerekli kılmıştır. (Dostoğlu, t.y., s.22) Bu dönemde yeni ipek fabrikaları Gökdere ve Cilimboz dereleri yakınlarına kurulmuş; çıkmaz sokaklara bağlantı sağlanmış, dar sokaklar genişletilmiş, kentin organik dokusunu bölen ana caddeler açılmış; hükümet, hastane, belediye, tiyatro, postane, banka, kaplıca otelleri gibi yapılar inşa edilmiş; modern eğitim veren okullar açılmıştır. 19.yy sonlarında Çekirge yolu üzerinde atlı arabalarla ulaşılabilen bahçeli lüks konutlar yapılmıştır. 1892'de tamamlanan Bursa-Mudanya demiryolu ile ihracat ürünleri Avrupa'ya taşınmıştır. Gelen göçmenler için ızgara planlı yeni mahalleler kurulmuştur. Açılan caddeler ve kurulan mahalleler 1939 hava fotoğrafında okunabilmektedir. (Şekil 5) I.Dünya ve Kurtuluş Savaşlarıyla süreç kesintiye uğramış, nüfus azalmış, mübadelelerle etnik yapıda değişimler yaşanmış, gayrimüslim girişimciler yitirilmiştir. (Tekeli, 1999, s.22)

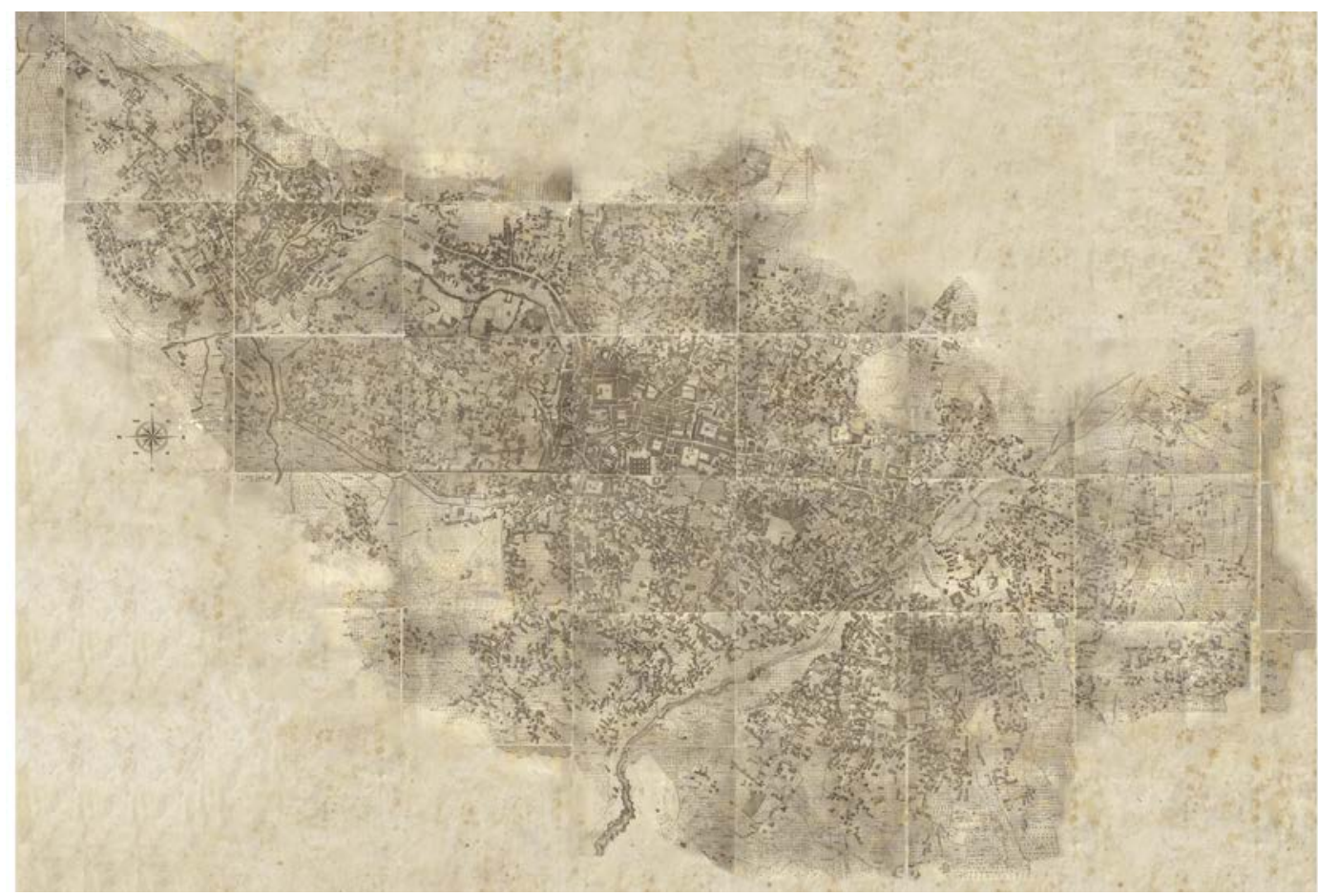

Şekil 4: 1862 Suphi Bey haritasında Bursa kent dokusu. (Bursa Büyükşehir Belediyesi- BBB arşivi)

Cumhuriyet sonrası dönemde Bursa'da sanayi gelişimini teşvik eden politikalar izlenmiş; 1933'te Birinci Sanayileşme Planı sonrası İpek-İş (1933), Merinos Dokuma Fabrikası(1938) gibi tekstil fabrikalarının yanı sıra gıda, makine üretim endüstrileri, selüloz, cam, porselen ve kimya gibi sanayileri içeren 16 fabrika kurulmuş, kırsal alanlardan kente göçler artmıştır. (Kaprol, 2000, s.174) 1941'de Çekirge turizm bölgesi ilan edilmiştir. Altıparmak Caddesi'nin açılışıyla yüksek gelir grupları kentin batısındaki bu bölgelerdeki konutlara yerleşmeye başlamıştır. 1924 yılında Karl Lörcher'e yaptırılan kent planı mevcut dokuya uygun bulunmadığından, 1940'ta Henri Prost'a yeni bir plan 
hazırlatılmış; Bursa ovasının verimsiz kesimlerini yapılaşmaya açmayı ve motorlu araçlara uygun yolları öneren plan 1960'lara kadar kenti yönlendirmiştir. 1958 yangını sonrası 1960'da hazırlanan Luigi Piccinato planıyla; tarihi dokuyu ve ovayı koruma amaçlı Ankara-Bursa-Mudanya ekseninde doğu-batı yönlü gelişme amaçlanmıştır. (Tekeli, 1999, s.24)

1962 yılında İstanbul'da hızlı büyümeyi kontrol etmek ve sanayiyi Bursa gibi civar illere desantralize etmek amacıyla yapılan Doğu Marmara Planı sonrasında, 1966'da Türkiye'nin ilk organize sanayi bölgesi (OSB) olarak kentten $14 \mathrm{~km}$ uzakta Mudanya yolu üzerinde Bursa OSB kurulmuştur. 1950'lerde Bulgaristan göçmenleri için kurulan Hürriyet Mahallesi ve çevresi, sanayi sonrasında işçi konutlarının yoğunlukta olduğu İstiklal, Adalet, Milliyet mahalleleriyle kuzeybatıya doğru büyümesini sürdürmüştür. 1970'lerin başında Tofaş ve Renault otomobil fabrikalarının açılmasıyla otomotiv yan sanayi atölyeleri artmıştır. 1960'lar sonrası yaşanan bu atılımlar Bursa'daki üçüncü kırılma olmuş; Piccinato planında 1980 tahmini 250.000 olarak belirlenen nüfus, alınan göçlerle 1975 'te 350.000 'e ulaşarak kentin kuzeyinde ovada, güneyinde yamaçlarda kaçak yapılaşmalara yol açmıştır. (Tekeli, 1999, s.26) Kent merkezinde ise az katlı binalar yüksek katlı apartmanlara dönüşmüş; ana caddelere yakın binalardaki konut işlevi yerini ticari birimlere bırakmıştır. (Dostoğlu, t.y., s.26,27)

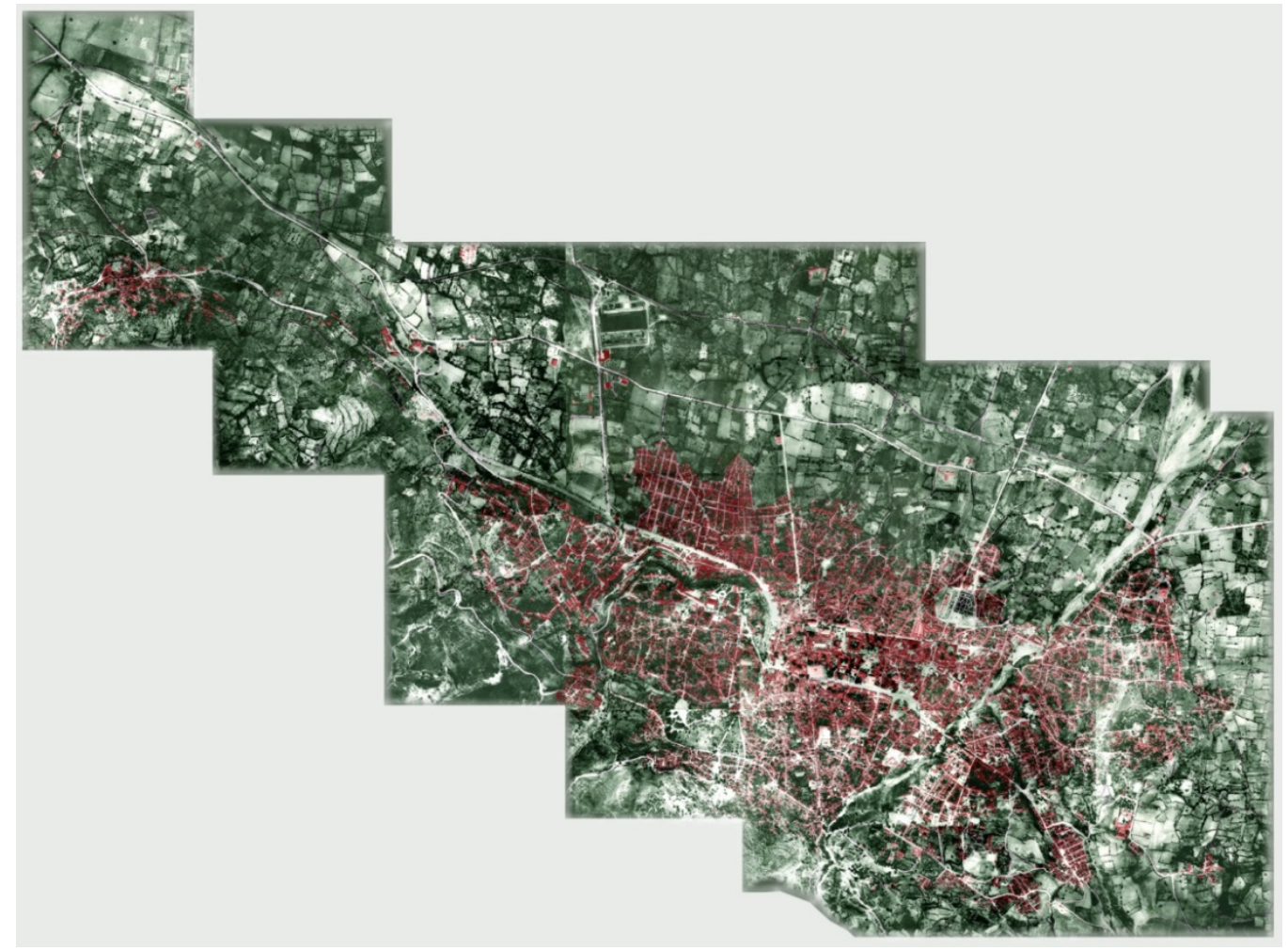

Şekil 5: 1939 yılı Bursa kent dokusu hava fotoğrafı. (BBB arşivi)

1976 Nazım Planı ve 1977'de Ova Koruma Protokolü imzalanmışsa da yasadışı konutların ve sanayi atölyelerinin oluşumu engellenememiştir. 1978'de 1/5000 ölçekte Bursa Arkeolojik, Doğal ve Tarihi Sit Alanları Koruma ve Geliştirme Planı hazırlanmış; ancak bu tarihe kadar özellikle 1965'te çıkan Kat Mülkiyeti kanunu sonrası apartmanlaşmaya maruz kalan sivil mimari örnekleri ve yol çalışmalarıyla tahrip olan anıt yapılar korunamamıştır. (Dostoğlu, t.y., s.26) 1984 Nazım Planı, 1990 ve 1995 Revizyon Nazım Planlarıyla; sanayi alanları kontrol altına alınmaya çalışımış, hızlı konut talebini karşılamak üzere Nilüfer toplu konut bölgesi olarak önerilmiştir. Otomobil 
sahipliliğinin artması, üst gelir gruplarının yeni, bahçeli, güvenlikli dışa kapalı siteleri tercih etmesi, 1980'lerin başında Görükle kampüsünde inşa edilen Uludağ Üniversitesi bölgeye talebi arttırmıştır.

1998'de onaylanan, 2009'da güncellenen, 1/100.000 ölçekli Bursa Çevre Düzeni Strateji Planı'yla ilk kez tanımlanan Bursa Metropolitan Alanı; Merkez, Doğu, Batı, Kuzey, Mudanya, Gemlik olarak yedi planlama bölgesine ayrılmıştır. Planlı gelişim, koruma ve sürdürülebilirlik, kültürel kimliği öne çıkarma hedefleriyle iyi bir başlangıç yapılmasına rağmen 1/25.000 ölçekli bölge planları tamamlanmadığından kent kendi dinamikleriyle hızlı gelişimine devam etmiştir. (Şekil 6) 2004'te Bursa Büyükşehir Belediye sınırlarına; Osmangazi, Yıldırım ve Nilüfer merkez ilçe olmak üzere Mudanya, Gemlik, Gürsu ve Kestel'i kapsayan 7 ilçe belediyesi, 18 ilk kademe belediyesi dahil edilmiştir. Yapılan otoyollar, 2002'de açılan BursaRay, 2007'de tamamlanan MudanyaGüzelyalı feribot iskelesi ve Uzak Çevre Yolu'nun açılması gibi gelişmeler İstanbul'a erişimi kolaylaştırmış; kent dokusuna, büyük ölçekli prestij projelerinin ve kuzey aksında lüks konut bölgelerinin artması şeklinde yansımıştır. (Eryılmaz ve diğ., 2008, s.8)

Ülkemizde 2000'li yıllarda başlayan kentsel dönüşüm uygulamaları Bursa'da da yaygınlaşmış (Dostoğlu, t.y., s.30), belediye planlamaları doğrultusunda intiyacı olan bölgelerde farklı boyutlarıyla ele alınarak yapılan dönüşümler kente katkı sağlarken; özel sektörü teşvik hedefiyle yapılan emsal artışları, dönüşümlerin esas ihtiyaç duyulan bölgeler yerine prestijli bölgelerde yapılmasına ve rant amaçlı yoğunluk artışlarına neden olmuştur.

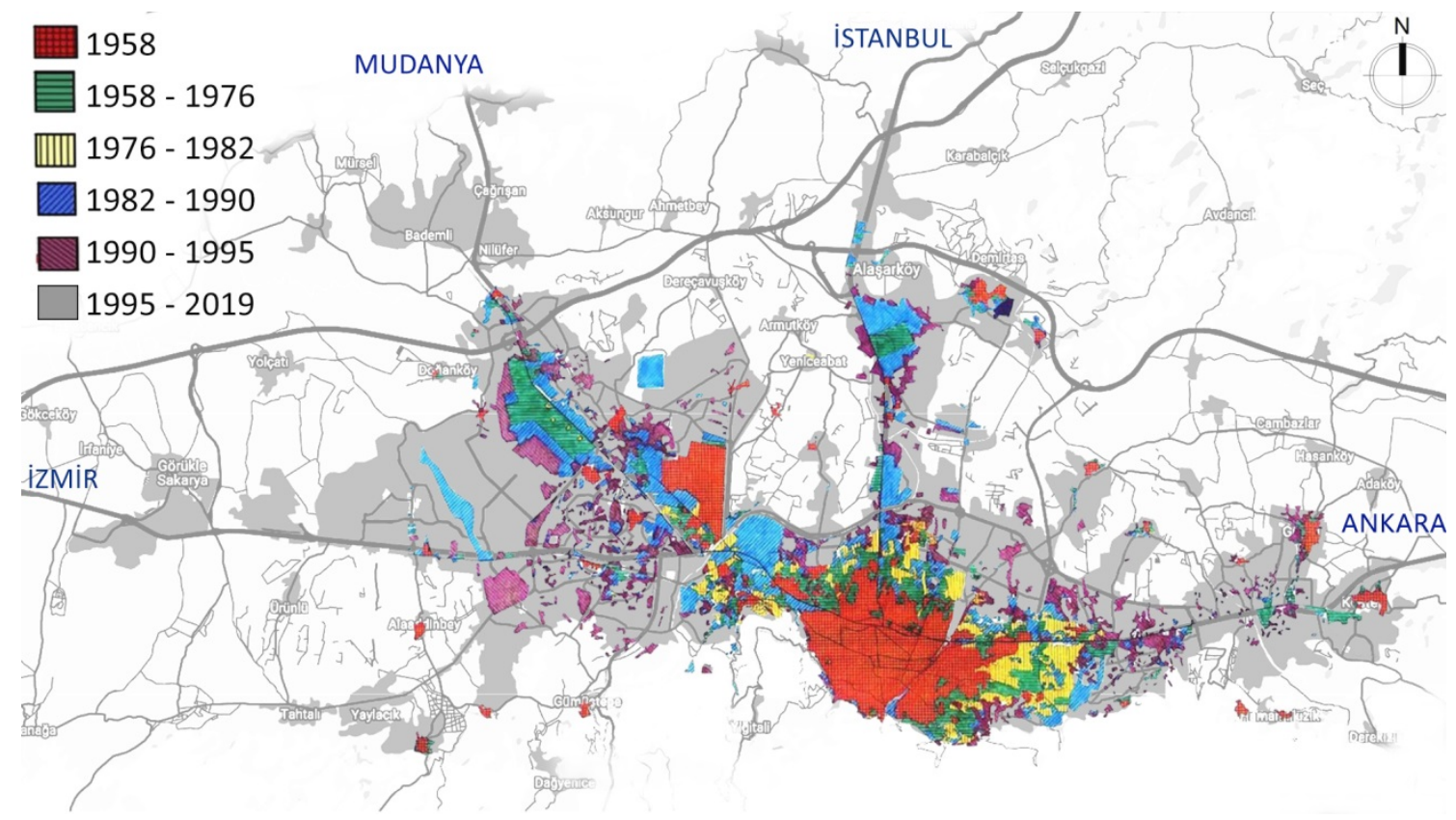

Şekil 6: Farklı yıllar arasında Bursa kentinin gelişimi. (BBB arşivinden alınan harita geliştirilerek hazırlanmıştır.)

Bursa'da 1927 yılında yaşayan kentli nüfusu \%28,6 oranındayken; 1960’lı yıllarda sanayileşme ve göçlerin etkisiyle kent nüfusunda yaşanan hızlı artışla 1970'te köy ve kent nüfusu oranı eşitlenirken, 2000 yılında kent nüfusu \%76,8 oranına ulaşmıştır. 2017 yılı TUIK verilerine göre Bursa ili toplam 2.936.803 kişilik nüfusuyla Türkiye'nin 4. kalabalık kenti konumundadır. (TUIK, 2017) Tarihsel süreci aktarılan Bursa kent morfolojisi bu bilgiler doğrultusunda sayısal analizlerle anlaşılmaya çalışılacaktır. 


\section{BURSA KENTI MORFOLOJIK DEĞişiMININ FRAKTAL ANALIZLERI}

Alan çalışması iki bölümden oluşmaktadır. İlk bölümde, Bursa kentinin 20.yy'ın ortalarından günümüze kadar geçirdiği morfolojik değişimi kavrayabilmek adına, farklı yıllardaki Bursa dokusunun 'kentsel ölçekte' analizleri yapılmıştır. Bunu yaparken Bursa Büyükşehir Belediyesi arşivinden alınan kentsel gelişim haritası (Şekil 6), Googleearth üzerinden ulaşılabilen 1985, 1990, 1995 uydu görüntüleriyle Photoshop programında çakıştırılıp doğruluğu test edildikten sonra, Cad ortamında 1958, 1976, 1982, 1990, 1995 yılları için yüksek çözünürlükte yeniden çizilmiştir. Çizilen yıllardaki kent lekeleri, ulaşım aksları yardımıyla 2019 uydu görüntüsüyle de çakıştırılarak son altmış yıllık kent gelişimi, bu altı yıla ait kent dokusu üzerinden analiz edilmiştir. Bursa Büyükşehir Belediyesi'nden alınan kentin en eski hava fotoğrafı olan 1939 yılı, mevcut çizimlere göre ölçeklendirilerek analize dahil edilmiş ve çalışmanın seyrini değiştiren bir katkı sağlamıştır. Böylece Bursa'nın son seksen yıllık süreci bu yedi yılın sayısal verileri doğrultusunda yorumlanmıştır.

Araştırmanın ikinci bölümünde ise, ilk bölümdeki verileri daha detaylı test etmek ve Bursa'nın en hızlı büyüme gösterdiği tespit edilen 1995 sonrası periyodundaki kent dokusu morfolojisini inceleyerek kentin nasıl yayıldığına dair kodları sayısal veriler yardımıyla çözmek amacıyla, ölçek büyütülmüş, çözünürlük arttırılmış ve 'bölgesel ölçekte' doku analizleri gerçekleştirilmiştir. Analiz edilecek bölgeler seçilirken; özellikle son 15 yılda Bursa'nın en çok değişim ve gelişim gösteren alanları üzerinde yoğunlaşılmış; kentin merkez-çeper, doğu-batı gibi farklı bölgelerinden, farklı dönemlerde oluşmuş, olgunluk düzeyi farklı dokularından seçim yapılmıştır. Geçmiş yıllara ait uydu görüntülerinin kalitesi de önemli bir etken olmuştur, bu açıdan bazı alanların 2003 ve 2019 yılları karşılaştırılırken; bazılarının 2006 ve 2019 yıllarındaki durumları analiz edilmiştir. Kentsel ve bölgesel ölçekteki tüm sayısal veriler ışığında zamansal ve mekansal benzerlik ve farklılıklar ortaya konmuştur.

\subsection{Kentsel Ölçekteki Analizler}

Bursa'nın gelişimi kentsel ölçekte; 1939, 1958, 1976, 1982, 1990, 1995, 2019 olmak üzere çizilen kent lekelerinin analizleri üzerinden ele alınmıştır. Bu bölümde üzerine en çok düşünülen nokta, kentsel sınırlar ile köy-kent ikilemi olmuştur. Köyler farklı yıllarda hem kırsal, hem de kentsel alanlara dahil olduğundan sınırların tanımlanması oldukça güçtür. Bunun yanında kentin büyüme biçimini daha net okuyabilmek amacıyla Bursa ve yakın çevresindeki köyler kentsel yerleşimle birlikte değerlendirilmiştir. Nitekim 2012'de çıkarılan 6360 Sayılı Kanunla birlikte, 2014 itibariyle köyler ve beldeler kentin birer mahallesi olarak nitelendirilmiştir. 1939 yılı için yararlanılan hava fotoğrafının sınırlı boyutu sebebiyle yalnızca bu yılda köyler analize dâhil edilememiş; bu durum avantaja çevrilerek o dönemdeki 'kent merkezi' dokusuyla sonraki yılların büyüme süreci karşılaştırılmıştır.

Haritalar 2480 piksel x 1740 pikselden oluşan $21 \mathrm{~cm}$ x 14,8 cm boyutlarındaki arka plan üzerine ölçeklendirilen kent lekelerini temsil etmektedir. Ölçek olarak 60 piksellik mesafe $1 \mathrm{~km}$ 'ye karşılık gelmektedir. FracLac programı kutu sayımı analizi üzerinden; kutu boyutları 2'nin 2'li kuvvetleri (power series) olarak ayarlanırken; maksimum kutu büyüklüğü detayların göz ardı edilmemesi adına görselin \%20'siyle sınırlandırılmıştır. Sonuçların güvenilirliği açısından 4 farklı ızgara konumu ile hesaplama yapılmıştır. Farklı kutu boyutları ve ızgara konumlarıyla ölçülen tüm değerlerin ağırıklı ortalaması alınarak görselin fraktal boyutu elde edilmektedir. Analizi yapılan haritaya ait sayısal 
değerler görselin altında belirtilmiş; faktal boyut; F, gözeneklilik değeri; $G$ ile gösterilmiştir.

1939-1958 yılları arası dönemde, şehrin dışında yapılanmaya başlayan Bursa Organize Sanayi Bölgesi ile kentsel dokuda yaşanan saçılma/ sıçrama ve 1958 kent lekesi analizine civar köylerin de dahil edilmesi dolayısıyla fraktal değerde 1,8152'den 1,5652'ye ani bir düşüş, gözeneklilik değerinde ise 0,1369'dan 0,6192'ye büyük bir artış ölçülmüştür. Takip eden yıllarda, giderek artan fraktal değer ve azalan gözeneklilik değeri yapılaşmış kent dokusu dağılımının zamanla daha homojen bir hale geldiğini ortaya koymaktadır. (Şekil 7)

1995'te 1,6967 olarak ölçülen fraktal boyut; 2019'da 1,8044'e ulaşarak, 1939'da 1,8152 olan kentsel fraktal boyuta en yakın ölçüm elde edilmiştir. Bu durum Bursa kentinde 1995 sonrasındaki 24 yıllık süreçte tüm parsellerin hızla yapılaştığını ve kentin hızlı yayılımının devam ettiğini göstermenin yanı sıra; erişilebilirlikteki artışla beraber, ana caddeler boyunca gelişen kent dokusunda, yerleşimler arası boşlukların dolmasıyla kentin kompaktlaştığının da bir kanıtıdır. 


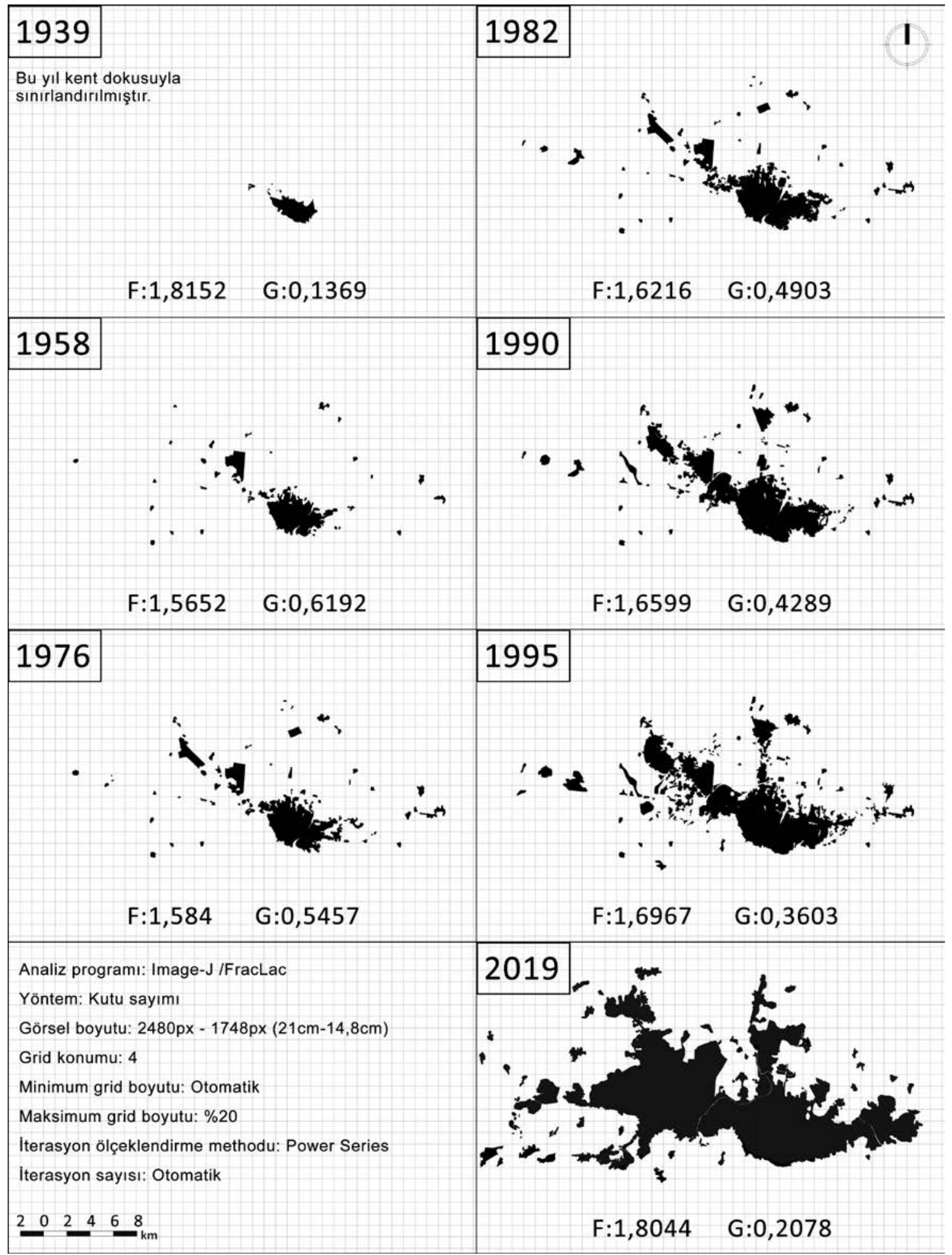

Şekil 7: Bursa kent dokusunun farklı yıllardaki fraktal ve gözeneklilik değerleri.

1939 ve 2019 yılı fraktal değerleri birbirine çok yakın ölçülse de; gözeneklilik değeri 0,1369 olan, kent merkeziyle sınırlı 1939 yılı kent dokusunun; 0,2078 gözeneklilik değerine sahip günümüz kentine göre çok daha kompakt bir kentsel çekirdek olduğu bir gerçektir. Ancak 80 yıl sonra bugün 'tarihi kent merkezi' olarak değerlendirdiğimiz alanın 1939 yılı verilerine bu kadar yakın rakamsal değerler elde edilmesi, 1958'den 
itibaren yoğunlaşarak büyüyen Bursa kenti bütününün, bugün kompakt merkezi özellikler gösterdiğini doğrular niteliktedir. (Tablo 1)

Tablo 1: Bursa'nın fraktal ve gözeneklilik değerlerinin yıllara göre değişimlerini gösteren eğri grafikleri.

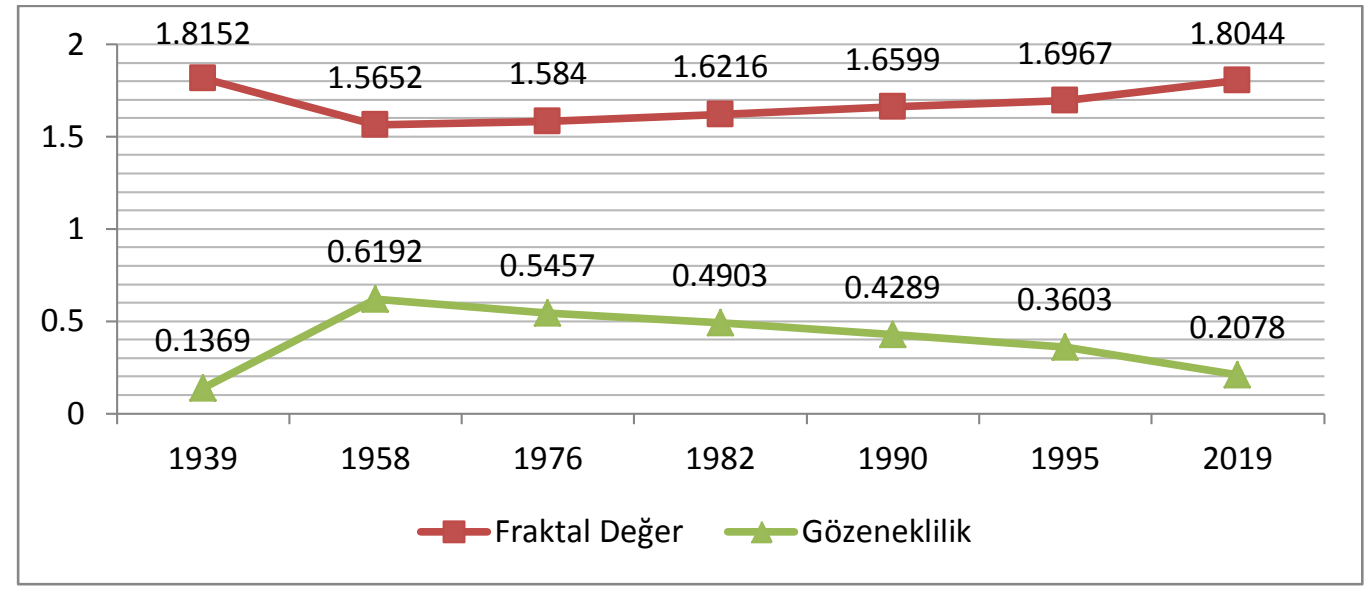

Kent lekesine uydu üzerinden bakıldığında 1990'lardan sonra yeni yolların açılması ve sanayi bölgelerinin kurulması gibi sebeplerle özellikle kentin batı ve kuzey yönlerinde Bursa ovasının hızla yapılaşmaya başladığı ve bu yapılaşmanın günümüzde de devam ettiği görülmektedir. 2019 sonu bitirilmesi planlanan İstanbul-Bursa-İzmir otoyolu yakın gelecekte Karacabey Bursa arasındaki tarım arazilerinin yapılaşmaya açılması yolunda yeni bir belirleyici etken olarak karşımıza çıkabilir. Ayrıca kentin $30 \mathrm{~km}$ batısında Karacabey yakınında yapılacak olan Bursa Teknosab-Teknoloji Sanayi Bölgesi de Bursa'nın batıya hızlı büyümesinin süreceğinin sinyallerini vermektedir. (Url 2)

\subsection{Bölgesel Ölçekteki Analizler}

Analiz programına sunulacak olan siyah-beyaz ikili görseller; google earth üzerinden seçilen alanların günümüz (2019) durumu ile en temiz geçmiş yılına ait haritası (2003, 2006) yüksek çözünürlükteki uydu görüntülerinden elde edilmiştir. Binalar ve asfalt yollar yapılı çevre olarak değerlendirilip siyah lekelerle ifade edilirken; yeşil alanlar, yapılaşmamış arsalar gibi tüm boşluklar, doğru verilere ulaşmak adına temizlenerek beyazla gösterilmiştir. 


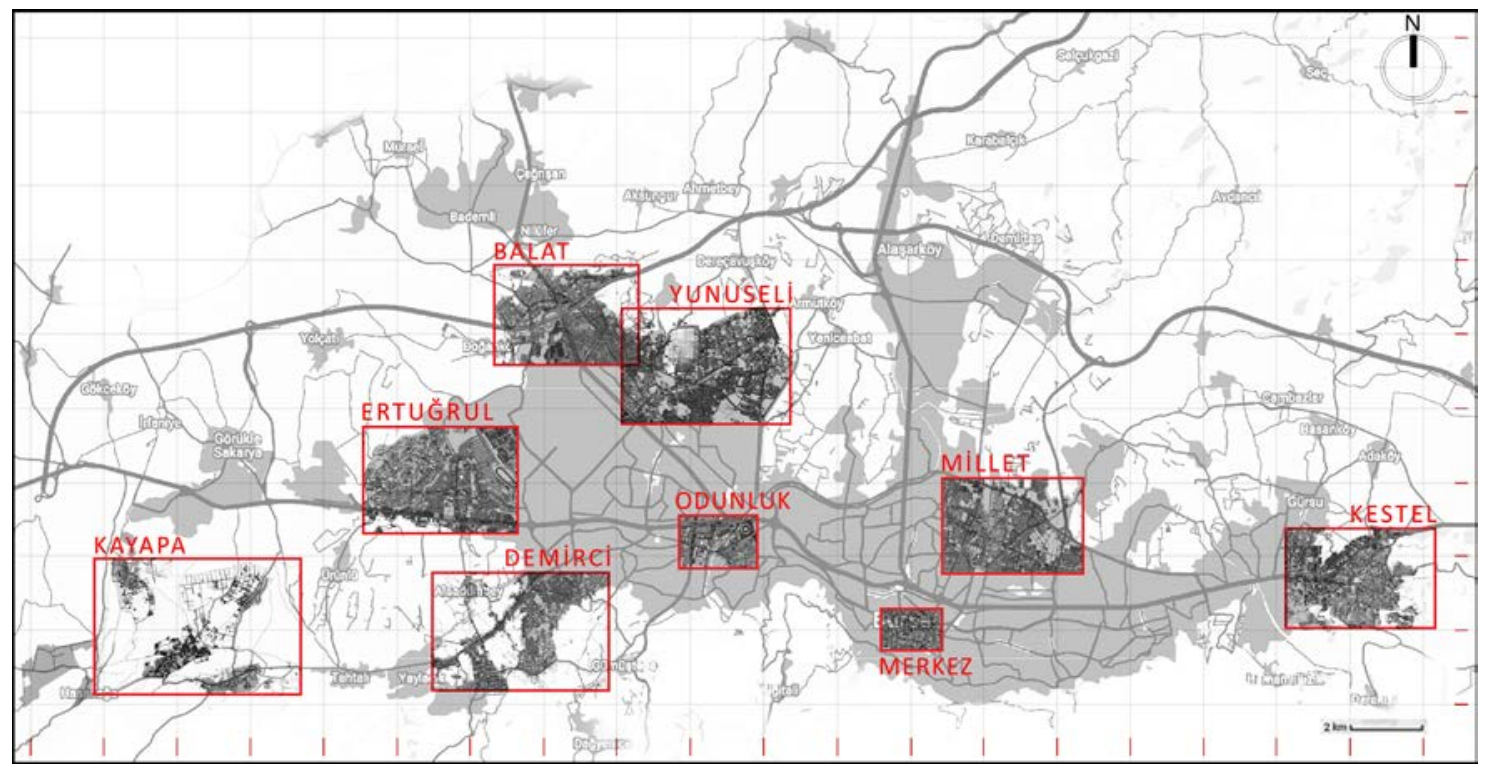

Şekil 8: Morfolojisi incelenecek olan bölgelerin Bursa kent dokusu içindeki yerleri.

Kent içinde son 15 yılda en çok değişen bölgeler araştırılırken, batı ve kuzeybatı bölgelerinin daha çok büyüme ve gelişme gösterdiği anlaşıımıştır. Bu sebeple kent merkezinin morfolojik verileriyle karşılaştırılmak üzere merkezin batısından Odunluk, Yunuseli, Balat, Demirci, Ertuğrul, Kayapa olmak üzere altı bölge; doğusundan ise Millet ve Kestel olmak üzere iki alt bölge seçilmiştir. (Şekil 8)

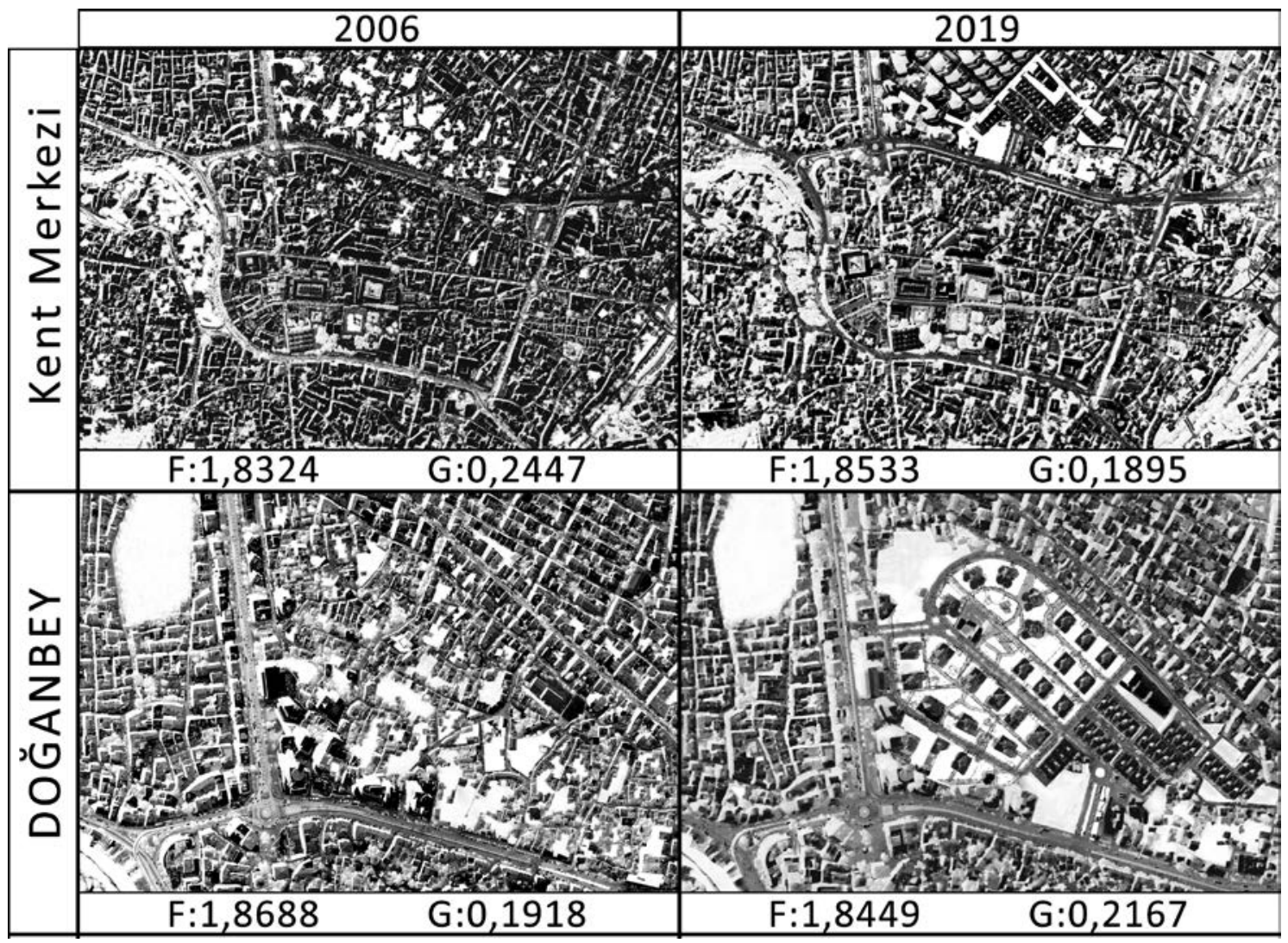

Şekil 9: 2006 ve 2019 yıllarında Bursa tarihi Hanlar Bölgesi çevresinin ve Doğanbey bölgesinin fraktal ve gözeneklilik değerleri. 
Illk olarak Bursa kent merkezinde 14.yy'ın ikinci yarısında inşa edilen ve hala merkezi özelliğini koruyan Hanlar bölgesi ve çevresi incelenmiştir. Organik kent dokusuna sahip bölgede Ahmet Vefik Paşa döneminde 1879-82 yılları arasında bugünkü Atatürk Caddesi olan Saray Caddesi genişletilmiş, Yeniyol/ İnönü Caddesi ve Altıparmak Caddesi açılmış; Belediye, tiyatro, postane, Osmanlı bankası gibi kamu binaları inşa edilerek merkez kimliği güçlendirilmiştir. Sonraki yıllarda 1909'da Mecidiye(Fevzi Çakmak) Caddesi,1913'te Hamidiye(Cumhuriyet) Cadddesi, 1970'de Haşim İşcan Caddesi açılarak bölge bugünkü haline gelmiştir. 1985'te Hanlar Bölgesi'nin ortasındaki alan bugünkü Orhangazi Meydanı olarak kamusal bir kimlikle yaya meydanı olarak yeniden tasarlanmıştır. 2000 yılında Bursa'nın ilk alışveriş merkezi olan Zafer Plaza AVM inşa edilerek alternatif bir kentsel odak olmuştur. 1995 sonrası dönemde kentin batıya doğru gelişmesi ve yüksek gelir grubunun Nilüfer, Balat, Beşevler, Ertuğrul gibi bölgeleri tercih etmesiyle kent merkezi alt ve orta gelir gruplarının yaşadığı, daha uygun fiyatlı konut ve ticari birimlere dönüşmüştür. 2014 yılında Unesco miras listesine giren alanlardan biri olan Ulucami'nin de içinde bulunduğu Hanlar Bölgesi, günümüzde hala tarihi, dini, ticari kimliğiyle kentliler ve ziyaretçiler tarafından en yoğun kullanılan merkez alanda, fiziksel dokunun fraktal değeri 2006'da 1,8324 iken; 2019'da 1,8533 olarak ölçülmüştür. Yoğun yapılı çevre karakteristiğinin ve aks sistemi korunarak karmaşıklığını sürdürdüğü anlaşılmaktadır. Öte yandan Hanlar Bölgesi'nin kuzeyinde bulunan, 2006'da çöküntü bölgesi olarak değerlendirilerek; Doğanbey, Tayakadın, Kiremitçi, Kırcaali mahallelerini kapsayan alanda 2729 konuttan oluşan Doğanbey Toki dönüşümünün inşa edildiği bölge daha yakından analiz edildiğinde ise fraktal değerin 1,8688'den, 1,8449'a düştüğü okunmaktadır. 0,1918'den 0,2167 değerine yükselen gözeneklilik değeri bölgede daha heterojen boşluklu alanların oluşturulduğunu göstermektedir. (Şekil 9) Ancak alana dair yapılan çalışmalar bu boşlukların sosyal donatılar bakımından yetersiz; 22-23 katlı konut bloklarının bağlamdan ve kent kimliğinden kopuk olduğunu ortaya koymaktadır. Ayrıca komşuluk ilişkileri, aidiyet hissi ve güvenlik algısının da dönüşüm sonrası azaldığı anlaşılmıştır. (Gür ve Dostoğlu, 2016, s.102,104) Var olan kent dokusunda; kentsel boşlukların dolması katmanlaşmayı ve fraktal değeri arttırırken; kent merkezindeki Doğanbey bölgesinde görüldüğü gibi mevcut bir kaotik doku kazınıp yerine daha boşluklu ancak bağlamdan kopuk yeni bir dokunun oluşturulması durumunda ise fraktal değer azalmaktadır. Çok katmanlı, tarihi geçmişe sahip dokuların 2'ye yakın değerler gösterdiği, modern örneklerin 1'e yakın değerler aldığı göz önünde bulundurulursa; müdahale sonrası fraktal değerdeki düşüş 'modernleşme' adı altında o bölgedeki kültürel birikimin silinmesi riski doğduğu anlamına da gelmektedir.

Thomas ve diğ., 'kentsel dokuda farklı ölçeklerde aynı fraktal kuralın geçerli olmasının beklenmemesini, hatta sabit bir ölçekte bile fraktal davranışın incelenen nesneye göre farklılaşabileceğini' vurgulamıştır. (Kaya ve Bölen, 2011, s.43) Dolayısıyla Bursa kent merkezi analizlerindeki bu farklılaşma da, kentin çoklu-fraktal (multi-fractal) özellikte olduğunu göstermektedir. 


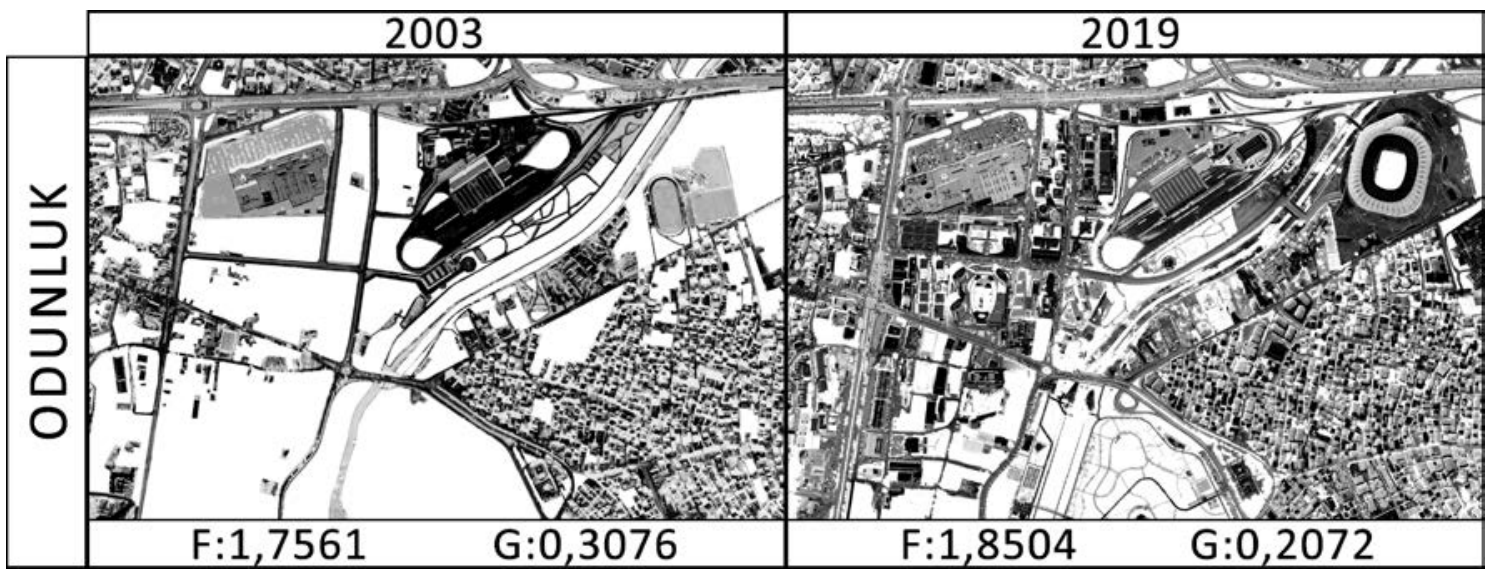

Şekil 10: 2003 ve 2019 yıllarında Odunluk bölgesi ve çevresinin F ve G değerleri.

İzmir Yolu ile Orhaneli Caddesi'nin kesiştiği bölgede bulunan Odunluk Mahallesi, 16.yy'da merkez ilçeye bağlı bir Türk köyüdür. Bölgeden geçen Nilüfer Çayı'na Uludağ'dan atılan odunlar bu köyde çıkarılıp depolanmıştır. 1916'da Rumeli göçmenlerinin yerleştirildiği köyde Kurtuluş Savaşı sırasında büyük tahribat yaşanmıştır. 1987'den bu yana Bursa'nın bir mahallesi olan Odunluk, Nilüfer ilçesine bağlıdır. (Kaplanoğlu, Url:3) Bölgede 2001 yılında açılan Carrefour AVM'nin ardından 2002'de BursaRay metro hattının sefere başlamasıyla gelişim hız kazanmış; Zeno Center, Mihraplı, Ofis Plus gibi prestijli iş merkezleri; Crown Plaza, Shereton Aloft, Gold Majesty gibi lüks oteller; Eker Meydan, ParkOra gibi yaşam merkezleri; Nilpark, Bauhaus, Sur Yapı Marka gibi AVM'ler; Misia, Harmony, Suryapı gibi dev karma fonksiyonlu projelerin merkezi konumuna gelmiştir. Bursa ulaşım ağının ortasında bulunan alanda 2015'te Timsah Stadyum'un yapımının tamamlanması ve Nilüfer Çayı çevresinde Mihraplı Park'ın açılması bölgenin kullanımını daha da artıran etmenler olmuştur. Sayısal olarak morfolojik dokusu incelenen park ve stadyumu da içine alan bölgenin fraktal boyutu 1,7561'den 1,8504'e artış göstermiştir. Bölge ve çevresi bugün kent merkezinden sonra en yoğun kullanılan merkez konumundadır. (Şekil 10)

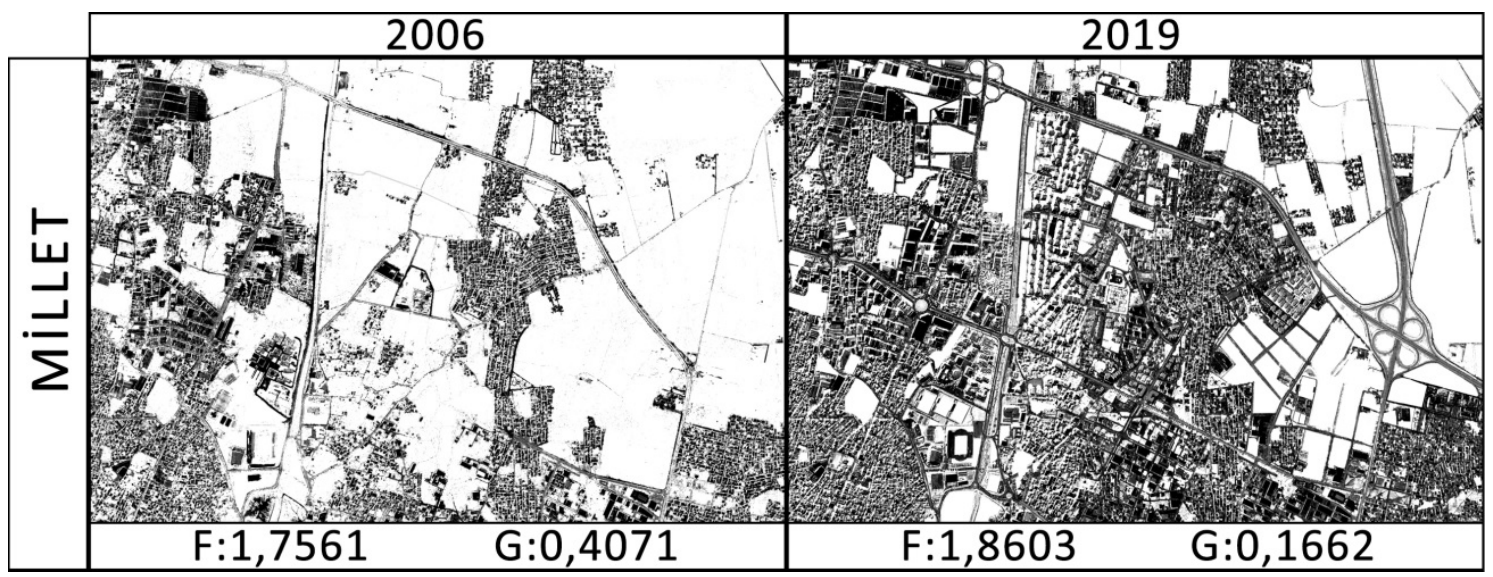

Şekil 11: 2006 ve 2019 yıllarında Millet Mahallesi ve çevresinin F ve G değerleri.

Yıldırım ilçesine bağıı olan Millet Mahallesi, Bursa'nın kuzeyinde, Samanlı Caddesi'nin kıyısındadır. Çoğunlukla Bulgaristan göçmenlerinin yaşadığı mahallede özellikle 20102017 yılları arasında yapılan kentsel dönüşümlerle büyük bir sıçrama yaşanmış; TUİK verilerine göre 2007'de 17.603 olan nüfus, 2017'de 60 bine ulaşmıştır. (Kaplanoğlu, Url:4) Bölgede yapılması planlanan projeler arasında 70bin metrekarelik kapalı alana 
sahip AVM, meydan, kapalı pazaryeri, okul ve kreş projeleri, bölgenin kentsel çeper alan olmaktan çıkıp kentle bütünleşerek bir alt merkez haline geldiğini göstermektedir. (Url:5) Analiz sonucunda 1,7561'den 1,8603'e kadar artan fraktal boyut ile 0,4071'den 0,1662'ye düşen gözeneklilik değeri de bölgenin bir merkez konumuna geldiğini destekler niteliktedir. (Şekil 11)

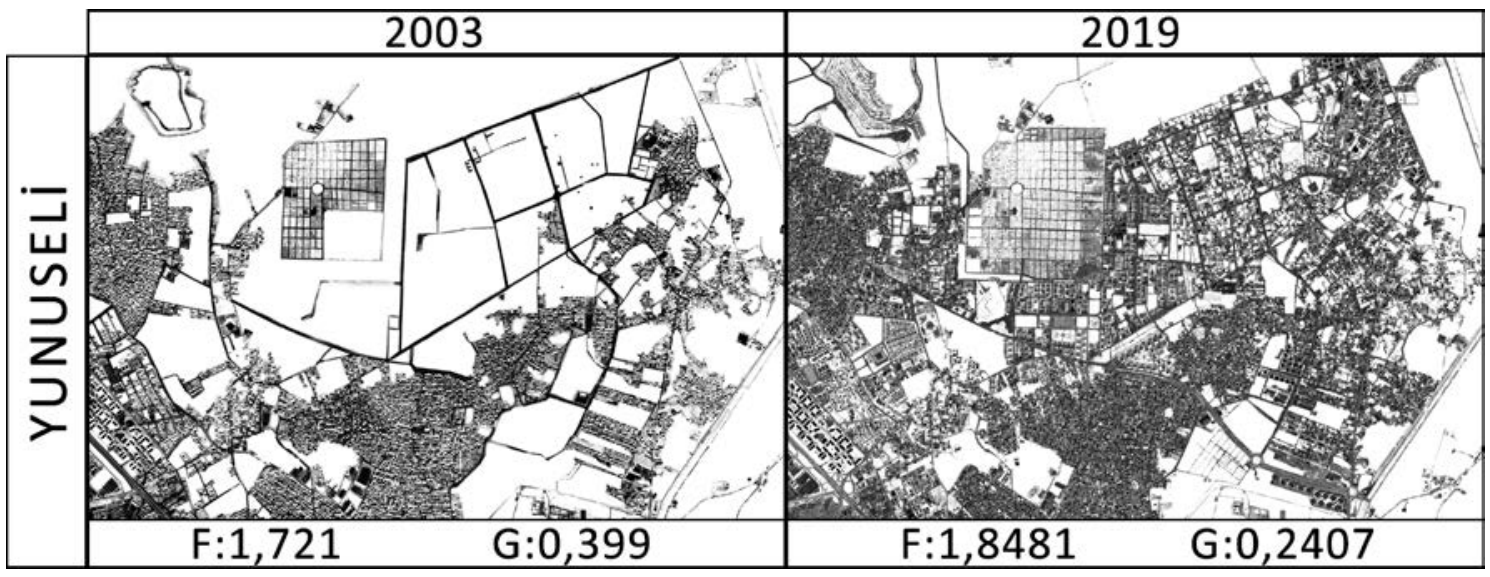

Şekil 12: 2003 ve 2019 yıllarında Yunuseli Mahallesi ve çevresinin F ve G değerleri.

Çeltik, Armut, Dereçavuş köyleri arasında kalan, eski adı Yunus'un beldesi anlamındaki Biladiyunus olan bölge 16.yüzyılda bir Rum köyü iken; Osmanlı Dönemi'nde, geliri Çekirge'deki imarete giden Sultan I.Murat'ın bir vakıf köyü konumuna gelmiştir. 1922'deki mübadeleyle, bölgede yaşayan Rumlar yerine Yunanistan ve Balkanlardan gelen göçmenler yerleştirilmiştir. 1987 yılında Osmangazi ilçesine bağlı bir mahalle olarak Büyükşehir Belediyesi sınırlarına dahil edilen Yunuseli ve batısındaki Hamitler mahalleleri son yıllarda Doğu Anadolu'dan yoğun göç almıştır. (Kaplanoğlu, Url:6) Fiziksel duruma baktığımızda, 2003 yılında mevcut dokunun yanına, Bursa Kent Mezarlığı'na kadar olan alanda, yeni yolların yapıldığı ve 2019'a kadar tüm boş parsellerin toplu konut siteleriyle dolduğu, 1,8481'e artan fraktal boyut ile 0,2407'ye düşen gözeneklilik değerinden de anlaşılmaktadır. (Şekil 12)

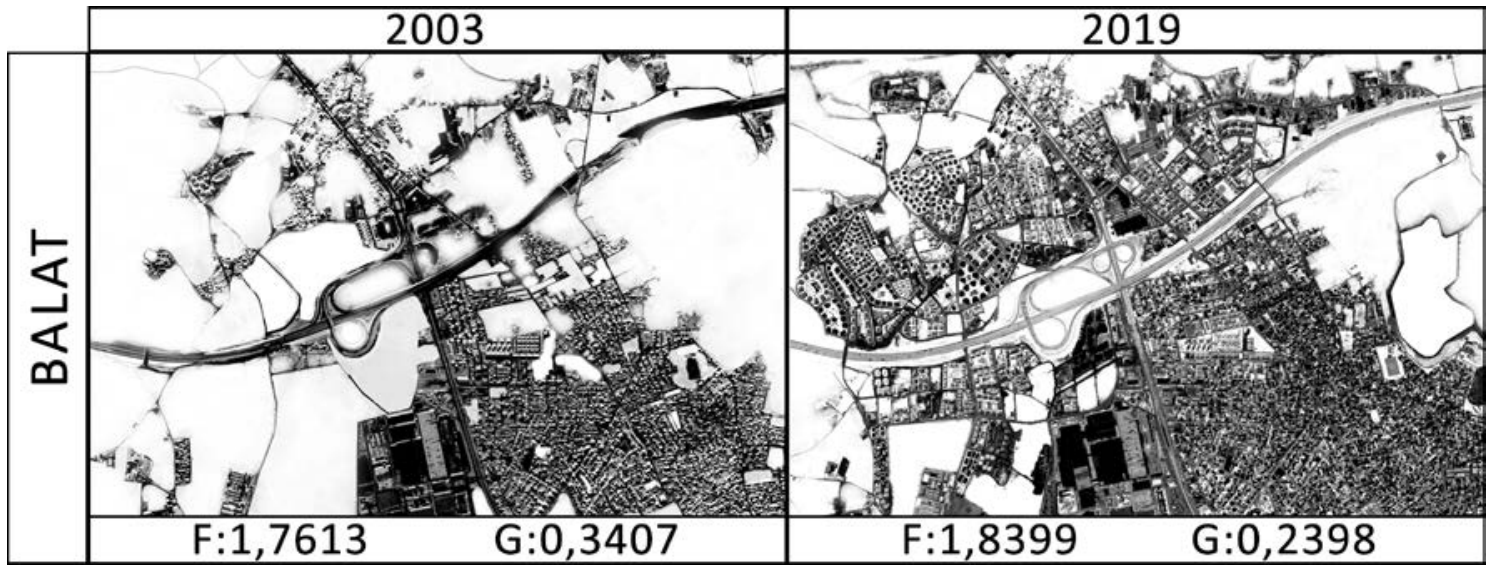

Şekil 13: 2003 ve 2019 yıllarında Balat, Geçit ve Emek bölgelerinin F ve G değerleri.

Bursa-Mudanya yolunun batısında bulunan Balat ve doğusunda bulunan Geçit, eski zamanlarda Bursa merkeze bağlı, İshak Şah vakfına ait olan Balat köyüne dahildir. Uzun yıllar çiftlik olan bu yerler şahıslardan satın alınıp 1890'larda köy kurulmuştur. (Kaplanoğlu, Url:7) 1953'te işletmeden kaldırılan eski Mudanya demiryolu da bu köydeki Koru istasyonundan geçmekteydi. (Url:8) Bir yerli köyü olan Balat, Geçit ve 
Emek bölgesine, 1966'da Bursa Organize Sanayi Bölgesinin kurulmasıyla Doğu Anadolu'dan gelen göçmenler de yerleşmiştir. Bölge 1987'de ayrı mahallelere dönüştürülerek belediye sınırları içine alınmıştır. Bugün Sanayi Caddesi'nin batısındaki Balat ve Bursa OSB Nilüfer ilçesine; caddenin doğusundaki Geçit ve Emek mahalleleri ise Osmangazi ilçesine bağlıdır. 2002'de Organize Sanayiye kadar açılan, 2010'da Emek'e kadar uzatılan Bursaray ve Bursa Çevre yolu bağlantısıyla bölgeye ulaşım güçlenmiştir. Son yıllarda çok sayıda villa ve lüks konut sitelerinin yapıldığı Balat ve Geçit bölgesi, Özdilek, Endülüs Park, Korupark gibi Avmlerin; Bamboo Park, Turkuaz Plus gibi alışveriş ve yaşam merkezlerinin yapılmasıyla Bursalıların sıklıkla kullandığı bir cazibe merkezi haline gelmiştir. Kent dokusu verilerinde de izlenen, 2003'ten bugüne yaklaşık 1,84'e kadar artan fraktal boyut ve 0,2398'e düşen gözeneklilik değeri artan karmaşıklığı yansıtmaktadır. (Şekil 13)

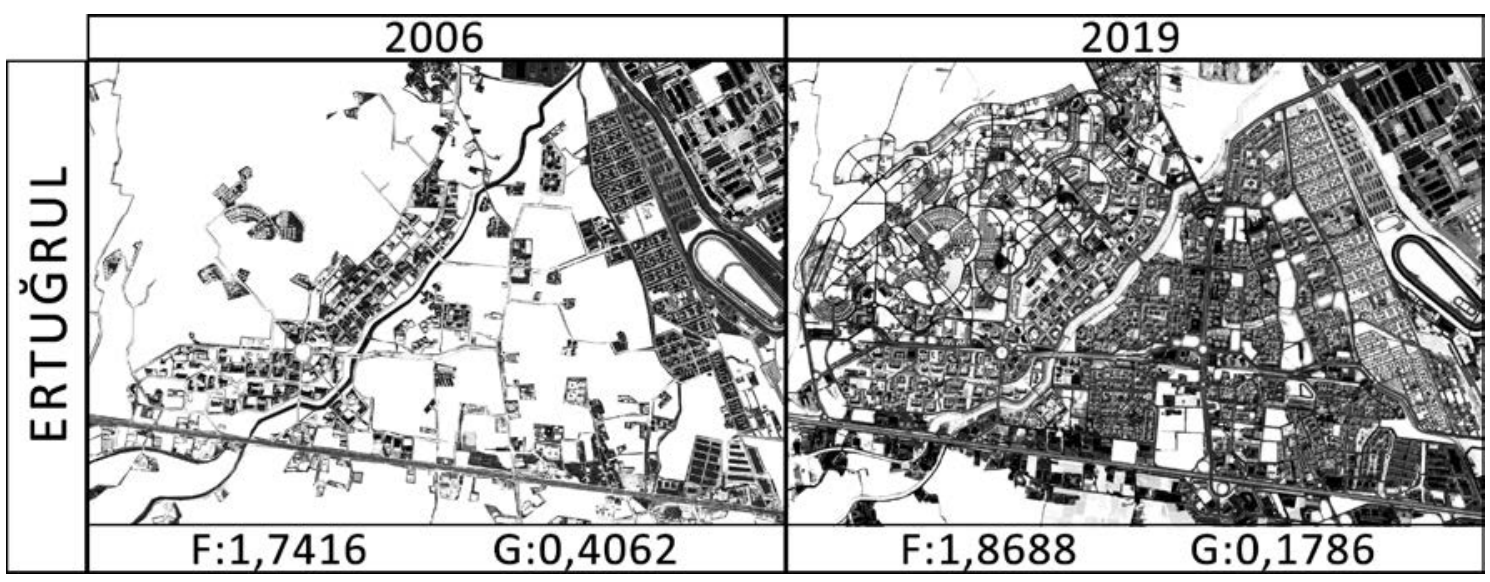

Şekil 14: 2006 ve 2019 yıllarında Ertuğrul, Özlüce ve Altınşehir Mahallelerinin F ve G değerleri.

Analiz edilen bir diğer alan Nilüfer ilçesine bağlı, Bursa-Karacabey yolunun kuzeyinde ve merkeze $11 \mathrm{~km}$ uzaklıktaki, Özlüce, Ertuğrul ve Altınşehir Mahallelerini içine alan bölgedir. Geçmişte İnesi olarak bilinen Özlüce, Görükle bucağına bağıı iken; Çayırköy olarak bilinen Ertuğrul ise Çalı bucağına bağlı, Rum ve Türklerin bir arada yaşadığı köylerdir. Kurtuluş Savaşı sonrası 1924'te mübadeleyle Yunanistan göçmenlerinin yerleştiği bölge; 1987'de belediye sınırları içine alınmıştır. (Kaplanoğlu, Url:9,10) Bölge özellikle Nilüfer ilçesinin hızla imar edildiği 1995 sonrası dönemde, konut kooperatifleri ve İzmir Yolu'na inşa edilen ticari yapılarla gelişimine başlamıştır. 2010'da Bursaray 2.etabın bitmesiyle üniversiteye kadar uzatılan metro hattı kentle bağlantıyı pekiştirmiştir. Uludağ Üniversitesi'ne ve sanayi bölgelerine yakınlığı, kolay ulaşılabilir olması, bahçeli ve kapalı konut sitelerine artan talep, hastane, okul, yeşil alan ve Bursaspor tesisleri, Hipodrom, Altınşehir Gençlik Merkezi, Nazım Hikmet Kültürevi gibi sosyal imkanlara sahip olması bölgeyi kısa sürede alternatif bir alt merkez haline getirmiştir. Son yıllarda Ertuğul ve Özlüce mahallelerinin ortasında bulunan, kafelerin ve alışveriş merkezlerinin yoğunlaştığı Ahmet Taner Kışlalı Bulvarı ve çevresi de Fatih Sultan Mehmet Bulvarı'na alternatif bir buluşma noktası olmuştur. Arena, Özdilekpark, Ardıçpark gibi Avmlerin yapılması, özel kolejlerin bu bölgeye taşınması gibi etmenler bölgedeki sirkülasyonu arttırmıştır. Bu doğrultuda 2006 ve 2019 analiz verilerine baktığımızda; 1,7416'dan 1,8688'e kadar artan fraktal boyut ve 0,4062'den 0,1786'ya düşen gözeneklilik değeri bölgenin son 13 yılda kaotik ve yoğun bir morfolojik doku haline geldiğini göstermektedir. Öyle ki Özlüce köyü çevresi tamamen sitelerle dolmuş, Ertuğrul köyü ise yol dokusu hariç özgün kimliğini kaybederek bitişik nizam apartman ve iş yerlerine dönüşmüştür. (Şekil 14) 


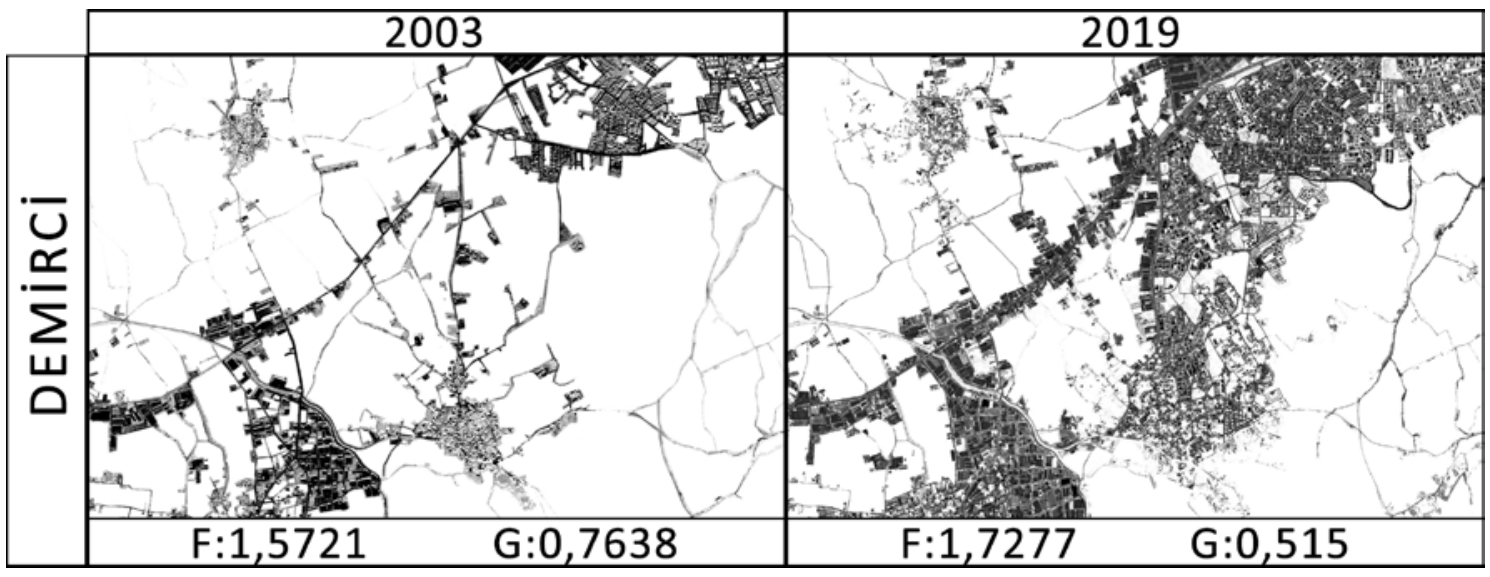

Şekil 15: 2003 ve 2019 yıllarında Demirci Mahallesi ve çevresinin F ve G değerleri.

Kentin batı çeperinde, son 15 yıl içinde hızla gelişen bir başka alan olarak; İzmir yolunun güneyindeki Demirci Mahallesi ve çevresindeki bölge analize tabi tutulmuştur. Çalı bucağına bağlı eski bir Rum köyü olan Demirci yakınlarında Roma ve Bizans dönemine ait, bugünkü Misi köyü de dahil, beş yerleşim alanı belirlenmiştir. Osmanlı döneminde 1500'lü yıllara ait kadı sicillerine göre Kite/ Ürünlü'ye bağlı bir vakıf köyü iken; 1987'de Belediye sınırları içine alınarak mahalle olmuştur. Bugün çoğunlukla yerliler ile Bulgaristan göçmenlerinin yaşadığı bir bölgedir. (Kaplanoğlu, Url:11) Doku morfolojisine bakıldığında 2003 yılında Demirci Mahallesi, kuzeyde Üçevler Mahallesi ile güneyde Çalı sanayi bölgesi arasında kalan Demirci köyü ve bağlantılı çiftliklerden ibaretti. Sanayi sitelerine ve İzmir Yolu'na yakın konumu, temiz hava ve orman gibi doğal güzelliklere sahip olması sayesinde batı yönünde gelişen kent içinde müstakil villalar için tercih edilen bir bölge haline gelmiştir. 2019'a gelindiğinde çiftliklerin kaldırıldığı, Sanayi bağlantısının güçlendiği ve Demirci köyü ile Üçevlerin yapılarla birleştiği görülmektedir. 1,5721'den 1,7277'ye artan fraktal boyut yoğunlaşmayı gösterirken bölgenin henüz merkez özelliğinde olmadığını anlatmaktadır. 0,7638'den 0,515'e düşen gözeneklilik değeriyse bahçeli konut dokusu ile boşluklu yapıdaki yerleşimin nispeten sürdürüldüğünü yansıtmaktadır. (Şekil 15)

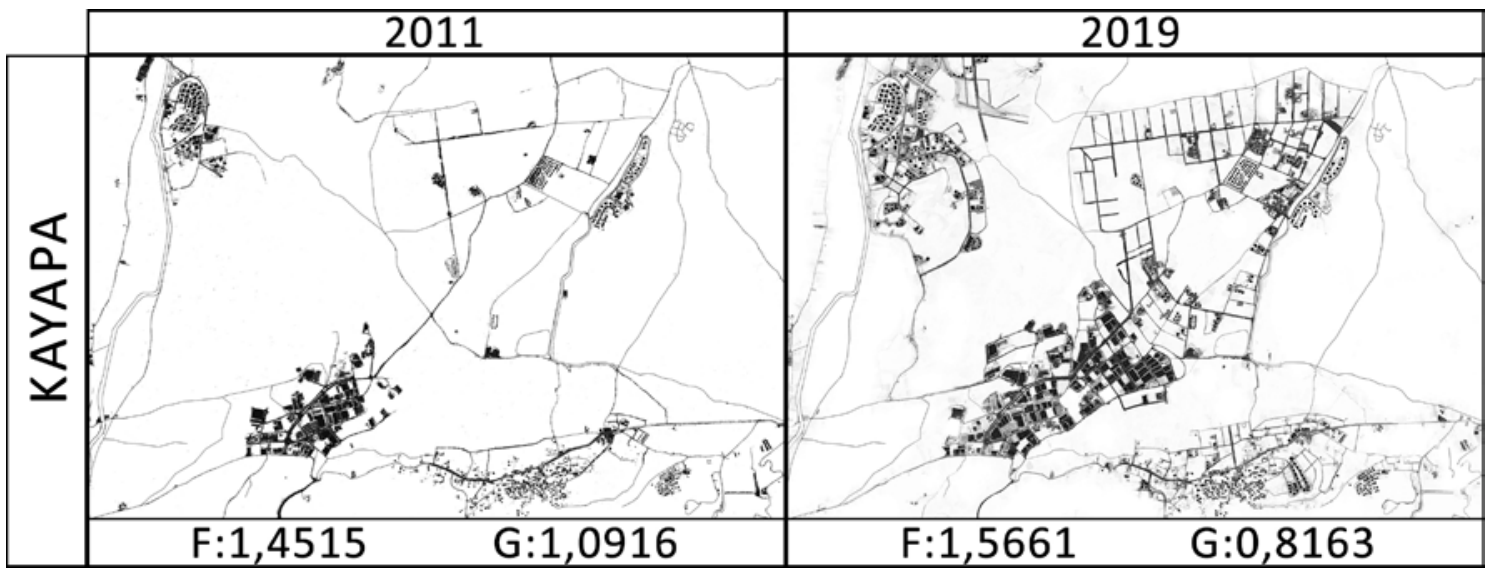

Şekil 16: 2011 ve 2019 yıllarında Kayapa ve yakın çevresinin F ve G değerleri.

Yeni oluşan, kentle henüz birleşmemiş bir doku örneği olarak; Bursa'nın batısında merkeze $17 \mathrm{~km}$ mesafedeki Kayapa ve $23 \mathrm{~km}$ mesafedeki Hasanağa bölgesi seçilmiştir. Bursa'nın fethinden önce Kayı boyuna mensup kişilerce kurulduğu düşünülen Kayapa bir yerli köyü iken; Hasanağa bir yörük köyüdür. Yakınlarında eski bir uygarlığın izlerine rastlanan ve bir Rum mezarlığı bulunan Kayapa'nın, Çelebi Mehmet'in vakıf köyü 
olduğu; eski adı Kızıkıı olan Hasanağa'nın ise geliri Çelebi Mehmet'in hizmetindeki Hasan Ağa isimli yeniçeri ağasına ayrılan bir köy olduğu anlaşılmaktadır. Uzun yıllar Kite/ Ürünlü'ye bağlı kalmışlardır. (Kaplanoğlu, Url:12,13) Yaklaşık 600 yıllık tarihe sahip bu iki köy ve çevresinde; İzmir yoluna yakınlığı, sanayi bölgelerinin açılması ve kentin batıya doğru büyümesiyle 2000'li yılların başında planlı kentsel yapılaşma başlamıştır. 1985'te izin verilen Hasanağa OSB 2003'te, Kayapa OSB 2014'te resmiyet kazanmış; Hasanağa'da 720 konut içeren Toki 2006'da, emekliler için yapılan 1201 konut içeren Toki ise 2018'de tamamlanmıştır. Analiz haritasına; Kayapa'nın 2009'da Nilüfer Belediyesine bağlanan Zafer, Çamlık ve İstiklal mahalleleri, Kayapa OSB bölgesi ve sol üstte, bugün Görükle Zafer mahallesiyle kuzeye doğru birleşme aşamasına gelen, Tokilerin bulunduğu Hasanağa, Kızıklı mahallesi dahil edilmiştir. 2011 yılı analiz verilerine göre 1,4515 gibi oldukça düşük bir fraktal boyuta, 1,0916 gibi yüksek gözeneklilik değerine sahipken; geçen 8 yıl içinde fraktal değerin 1,5661'e yükseldiği, gözenekliliğin ise 0,8163 'e düştüğü ölçülmüştür. Günümüz haritasında okunan yeni yapılaşmaların da habercisi olan yol dokusu, yakın gelecekte alanın daha da yoğunlaşacağını göstermektedir. (Şekil 16)

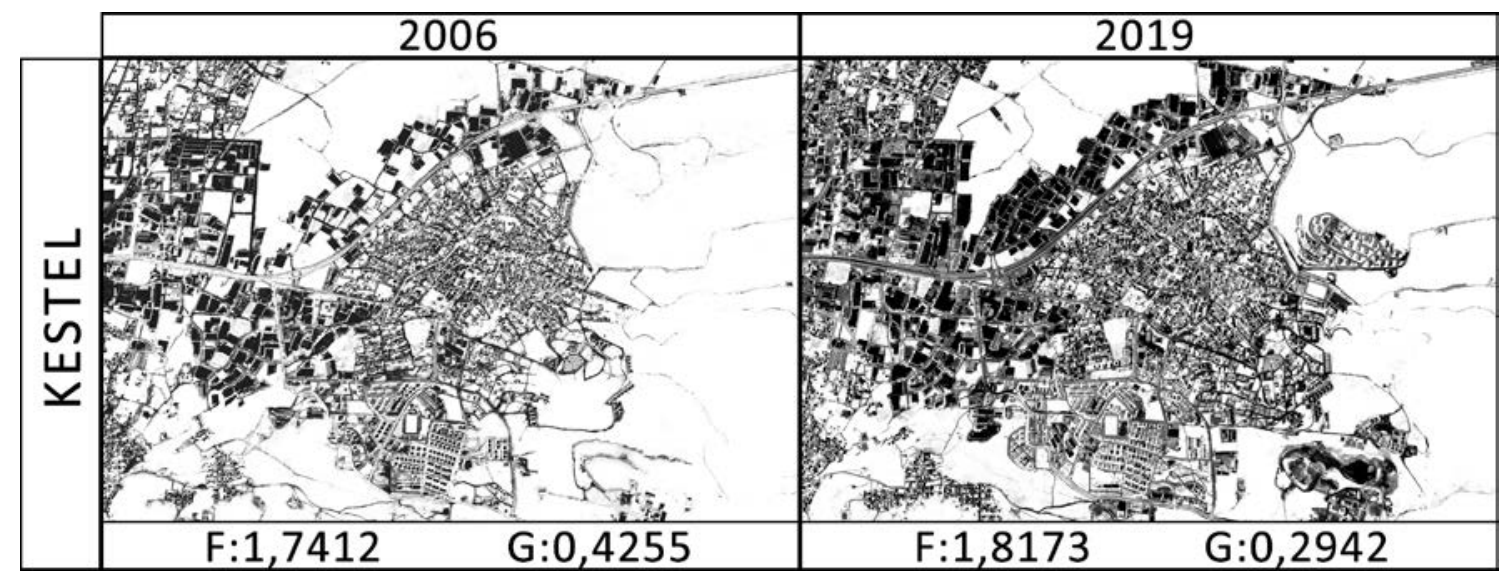

Şekil 17: 2006 ve 2019 yıllarında Kestel ilçesinin F ve G değerleri.

Kentin $12 \mathrm{~km}$ doğu çeperinde bulunan Kestel, Doğu Roma İmparatorluğunun sınır kalesi olması nedeniyle eski adı Latince'de Kalecik anlamına gelen 'Kastel' dir. 1306'da Osmanlı tarafından alınan Kastel'de, ilerleyen yıllarda Mehmet Vani Efendi'nin cami, imaret, medrese, fırın, hamam ve değirmen yaptırmasıyla yerleşim başlamıştır. 1900'lü yıllarda yurt dışından çoğunlukla Bulgaristan'dan, yurt içinden Bilecik, Tunceli, Erzurum, Elazığ, Bayburt, Artvin, Muş bölgelerinden göç almıştır. Merkez bucak olan Kestel 1960'da belde olup belediye teşkilatını kurmuş, 1990 yılında ilçe kabul edilmiştir. (Url:14) 2004'ten beri BBB sınırlarına dahil yedi merkez ilçeden biridir. Bugün tarım ve sanayi potansiyeline sahip olan bölge 2004'te aldığı tescil belgesiyle OSB statüsüne kavuşmuştur. (ŞPO, 2009, s.87-88) Topografik şartlar nedeniyle alansal büyüme imkanı sınırlı olan bölgede 2006'dan bugüne var olan dokunun yoğunlaştığı görülmektedir. 2009 yılında tamamlanan 716 konutluk Toki projesi ve 2012'de Toki ikinci etabın yapılması bölge nüfusunu artırmıştır. 2008'de Arabayatağı'na kadar inşa edilen BursaRay hattının 2014'te Kestel'e kadar uzatılması, 2016'da aktarmasız işletime başlaması Bursa ile bağlantıyı güçlendirmiştir. 1,7412'den 1,8173'e çıkan fraktal boyut bölgenin kendi içinde bir alt merkez konumuna geldiğini, 0,4255'den 0,2942'ye düşen gözeneklilik değeri ise kentsel dokudaki boşlukların dolduğunu anlatmaktadır. (Şekil 17) 


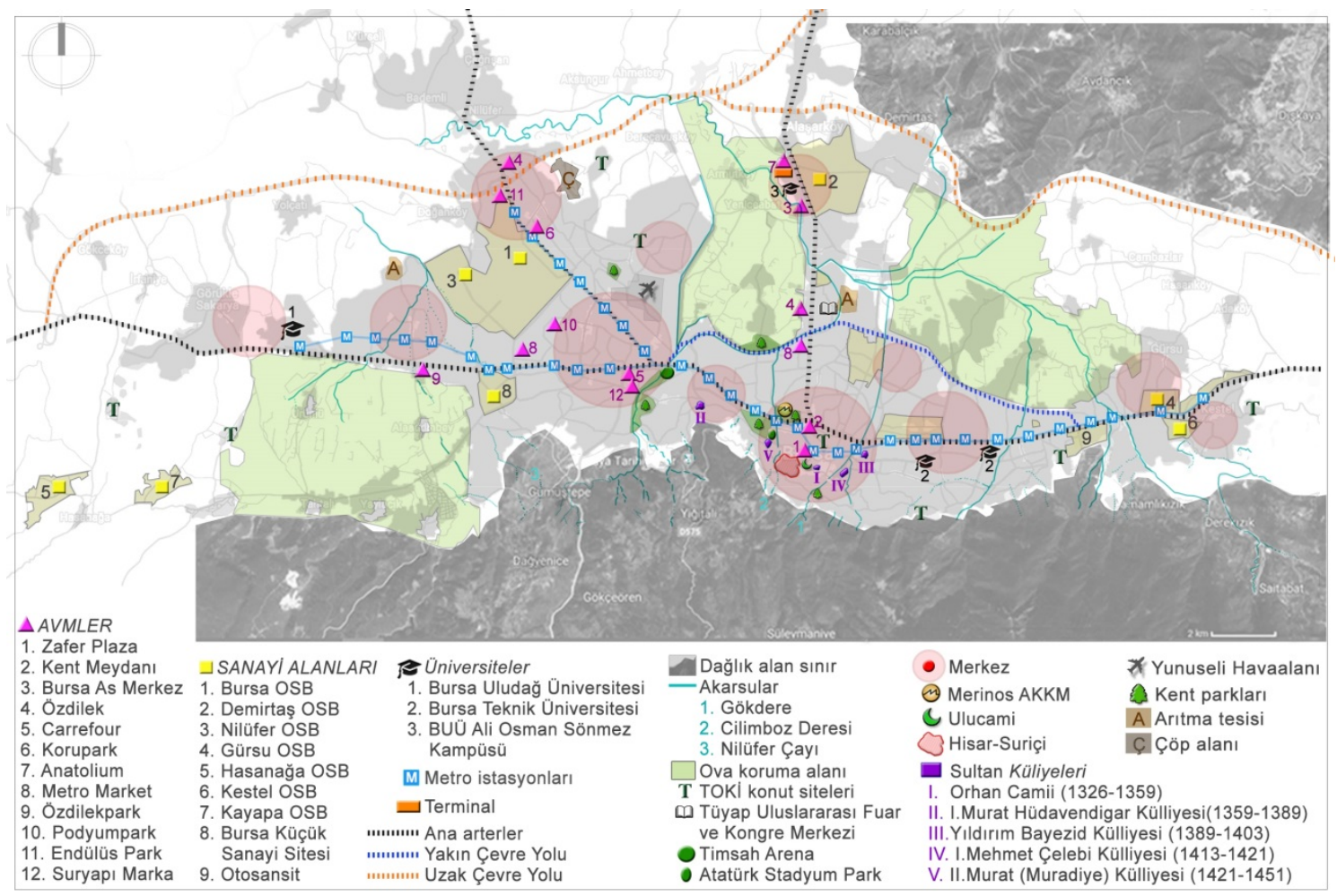

Şekil 18: Bursa kenti bileşenleri, doğal sınırları, ana ulaşım aksları, kentsel odakları ve merkez alanları.

Bu bölümde Bursa kentinde, kent merkezinin karmaşıklık seviyesine yaklaşma eğiliminde olan pek çok yeni alt merkezin oluştuğu ve kentsel ölçekteki analizlerde de okunduğu gibi kentin tamamının kompakt bir merkez gibi davrandığı anlaşılmıştır. (Şekil 18) Her alt bölge morfolojisinin kendi içinde, oluştuğu dönemin sosyo-kültürel ve ekonomik yapısını yansıttığı düşünüldüğünde, son 15 yıllık değişimi incelenen kentin farklı bölgelerindeki farklı kimliklere sahip alanlarda, özellikle konut dokusunda 'benzer' yapılaşma karakterlerine sahip kapalı konut sitelerinin yapıldığı ve kentlilerin talebinin de bu yönde yoğunlaştığı dikkat çekmektedir. Bölgelerdeki sayısal değerlerin birbirine yaklaşması da kent içi alanların birbirine benzer morfolojilere evrildiğini göstermektedir.

Ayrıca alt alanlarda dikkati çeken bir diğer nokta kendiliğinden oluşan plansız yerleşimler arasındaki ve çevresindeki boşlukların zamanla planlı bir şekilde doldurulmasıdır. Kent dışında kalan köyler yasal olarak 2014 yılında mahalle statüsü kazanırken, fiziksel olarak da kentsel doku sınırları içinde kalmıştır. Yeni yolların yapılması ve hızlı yapılaşmayla kent içinde ya da yakınında kalan köy topraklarının maddi değeri artarken, yerleşim dokuları hızlı kentleşme etkisiyle tahribata uğramıştır.

Kentsel büyümenin; kentteki boşlukların dolması ve kent çeperinde yayılma göstermesi ile kente 'eklenmesi', kent dışında bir yerde yeni oluşan bir dokunun zaman içerisinde var olan kente 'eklemlenmesi' olarak iki şekilde gerçekleştiği anlaşılmıştır. Kent dokusunun 'mürekkep lekesi gibi' çevresindeki boşluklara yayılması 'kente eklenme' şeklinde olduğunda kent lekesinin fraktal değerini arttıırken (1958 sonrası veriler); büyüme 'dokudaki bir sıçrama, saçılma' şeklinde ise kent lekesinin fraktal değerini azaltan bir etki yaratmaktadır (1939-1958 yılları arasında görülen saçılma etkisidir).

Bursa kentinin morfolojik gelişiminde en büyük belirleyici etkenlerden biri sanayi bölgelerinin konumları olmuştur. Önceleri kent dışında, kentten kopuk olarak kurulan 
OSB'lerin çevresindeki boş alanlar hızla konut yapılaşmasıyla dolmuş, bu bölgeler zaman içinde kentsel doku içinde kalarak alt merkez olacak kadar gelişmiştir.

\section{SONUÇ VE DEĞERLENDIRRME}

Çalışma kapsamında, morfoloji çalışmalarında yeni bir yaklaşım olan fraktal ve gözeneklilik analizleriyle kent morfolojisinin; zamansal ve mekansal farklılaşma veya aynılaşma durumları Bursa kent dokusunun farklı ölçeklerindeki sayısal verilerin değişimi üzerinden sorgulanarak yorumlanmıştır. Kullanılan sayısal analizlerde, kentsel doku oluşum ve değişimini daha somut verilerle kavrayabilmek amacıyla; belirlenen parametreler sabit tutulup, diğer parametreler değiştirilerek adeta bir kontrollü deney titizliğiyle morfolojik bir kent çözümlemesi yapmak hedeflenmiştir.

Ulaşılan sonuçlar şöyle sıralanabilir;

- Kentsel doku, farklı ölçeklerinde kendine benzer özellikler gösteren 'çoklu fraktal' bir yapıya sahiptir ve kente eklenme veya eklemlenme şeklinde büyümektedir.

- 1950'lerden sonra Bursa dokusunun kent çeperlerine doğru yayıldığı ve Organize Sanayi bölgelerinin kurulmasıyla yayılma sürecinin hızlandığı görülmüştür. Yeni yapılaşan alanların birçoğu Bursa ovası ve tarım arazileridir.

- Bursa kenti özellikle batı ve kuzeybatı yönlerinde daha hızlı yapılaşma göstermiştir. Nilüfer ilçesinin kurulması, yeni yerleşimlere artan talep, ulaşım olanaklarının gelişmesi, İstanbul'a yakınlık ve göçle gelen nüfus artışı gibi sebepler belirleyici olmuştur.

- 2019 yılı verilerinin 1939 yılı verilerine yaklaşma eğiliminde olması, günümüz Bursa'sında kentsel ölçekte yayılmanın ve mevcut boşlukların dolmasıyla kompakt gelişmenin bir arada olduğunu gösterirken; alt alan ölçeğindeki veriler de kent genelindeki kompaktlaşmayı destekler niteliktedir. Nitekim yaklaşık son 15 yıllık süreçteki morfolojik değişimi (morfogenetiği) incelenen farklı olgunluktaki kentsel alt bölgelerin karmaşıklık düzeylerinin ve fraktal değerin kent merkezi değerlerine yaklaşma eğiliminde olduğu, yani kompaktlaşarak kendi kendine yetebilen birer alt merkez durumuna geldiği verilerle okunmuştur. Kent çeperinde oluşan genç dokuların da benzer fiziksel gelişim sürecini izleyeceği öngörülmektedir. Bu durum kentlerin fraktallere ait olan farklı ölçeklerdeki 'öz benzerlik' ve 'başlangıç koşullarına bağlıık' özellikleri gösterdiğini kanıtlamaktadır.

- Dokuda kendiliğinden değişimin daha yavaş gerçekleştiği ve sayısal değerlere az etki ettiği okunurken; yol yapımı, kentsel dönüşümler gibi planlı müdahalelerle yapılan değişimler mekan organizasyonuna ve sayısal değere daha hızlı etki eden farklar olarak yansımıştır. Son 15 yıllık değişimi incelenen alt alanların hemen hepsinde planlı ve hızlı değişim süreci verilerde okunmuştur. Ayrıca aynı kentsel dokuda planlı ve kendiliğinden değişimin birlikte var olabileceği, bu yerler arasında kesin sınırlar olmadığı; Ertuğrul, Özlüce, Demirci köyleri gibi kent dokusu içinde kalan kırsal dokular ya da Millet Mahallesi örneğindeki gecekondu bölgesinde yapılan planlı dönüşüm projesi gibi alt alan ölçeğindeki örneklerle de okunabilmektedir.

- Kent dokusunun fraktal değerinin belirli bir noktadan sonra daha yavaş arttığı görülmekte ve buradan dokunun taşıyabileceği kapasiteye eriştiği anlaşılmaktadır.

Bir kent morfolojisini anlamak adına, fraktal analiz tek başına yeterli olmamakla birlikte; kentin tarihi, coğrafi, siyasi, beşeri, ekonomik, sosyo-kültürel dinamikleriyle ilişkilendirilerek; zaman, mekan ve ölçek farklılaşması yoluyla örneklem alanlar çeşitlendirildiğinde son derece açıklayıcı veriler sunduğu görülmüştür. Özellikle analiz edilecek kent dokusunun analize hazırlık aşaması doğru sonuçlara ulaşabilmek 
açısından büyük önem taşımaktadır. Doku görselinin çözünürlük kalitesi, ölçeğin gerektirdiği detay seviyesinde olması, kentsel doluluk ve boşlukların doğru ifade edilmesi sağlıklı sayısal veriler elde etmenin ön koşuludur.

Yapılan çalışmada, Bursa'nın kentsel büyüme biçimi ve hızının sürdürülebilirlik açısından yeniden ele alınması gerektiği ortaya konmuştur. Bu araştırmadaki çok boyutlu yaklaşım kaotik kentsel dokunun kendine özgü büyüme sürecini anlayabilmek, karakterize edebilmek ve çevresel farkındalığı arttırmak adına önemli görülmektedir.

\section{KAYNAKLAR}

Arrouf, Abdelmalek; Kacha, Lemya; Mansouri, Ahmed, "A Fractal Measurement of the Morphological Identity for Some Urban Fabrics in the Algerian City of Batna", Cybergeo, 2015, s.n.y. (Url: https://journals.openedition.org/cybergeo//27331 , erişim tarihi: 09.01.2019)

Bursa Büyükşehir Belediyesi (BBB), www.bursa.bel.tr

Bovill, Carl, "Fractal Geometry in Architecture and Design", Birkhauser Boston, 1996, Ss. 195.

Caglioni, Matteo; Giovanni, Rabio, "Contribution to the Fractal Analysis of Cities: A Study of the Metropolitan Area of Milan", Cybergeo (European Journal of Geography), 2006, s.n.y. (Url: https://journals.openedition.org/cybergeo/3634 , erişim tarihi: 15.11.2018)

Dostoğlu, Neslihan, "Bursa'da Geçmişten Günümüze Kentsel ve Mimari Değişim”, Osmangazi Belediyesi Hisar Dergisi, 'Eskinin Bursa'sı' sayısı, t.y., ss. 20-31.

Ediz, Özgür, "Mimari Tasarımda Fraktal Kurguya Dayalı Üretken Bir Yaklaşım", ITÜ FBE, Dr. Tezi, 2003, ss.185.

Ediz, Özgür; Ostwald, J.Michael, "The Süleymaniye Mosque: A Computational Fractal Analysis Of Visual Complexity And Layering In Sinan's Masterwork", Architectural Research Quarterly (Arq), 2012, ss.171-182.

Eryılmaz, Semiha Sultan; Cengiz, Hüseyin; Eryılmaz, Yaşasın, "The Urban Sprawl Model for an Affected Metropolis: Bursa-Istanbul Example", 44th ISoCaRP Congress 2008.

Gözübüyük, Gaye, "Farklı Mimari Dillerde Fraktallere Dayalı Form Üretimi”, ITÜ FBE, YI. Tezi, 2007, ss.154.

Gür, Miray; Dostoğlu, Neslihan, "Bursa Doğanbey Üzerinden Kentsel Dönüşümde Yaşam Kalitesinin Tartışılması", Megaron Dergisi, 2016, cilt:11, sayı:1, ss.89-105.

Josephine, Vaughan; Ostwald, J.Michael, "Nature and architecture: revisiting the fractal connection in Amasya and Sea Ranch", 43rd Annual Conference of the Architectural Science Association, ANZAScA, 2009, s.n.y. 
Kaplanoğlu, Raif, “Bursa'nın Tarihsel Gelişmesi”, Bursa Defteri, Editör: Hacı Tonak, Bursa, Mayıs 2008, sayı: 31-32, ss. 39-51.

Kaprol, Timur, Cumhuriyet Sonrası 1930-1950 Yılları Arasında Bursa'da Mimari Gelişim, Uludağ Üniversitesi Mühendislik-Mimarlık Fakültesi Dergisi, Bursa 2002, Cilt 7, Sayı 1.

Kaya, H. Serdar, "Kentsel Dokunun Dinamik Yapısının Analizine Yönelik Sayısal Yöntem Önerisi”, ITÜ FBE, Şehir Bölge Planlama Anabilim Dalı, Dr. Tezi, 2010, ss.280.

Kaya, H. Serdar; Bölen, Fulin, "Kentsel Dokudaki Değişimin Fraktal Geometri Yöntemiyle İncelenmesi”, itüdergisi/a, Cilt:10, Sayı:1, Mart 2011, ss. 39-50.

Kubat, Ayşe Sema; Topçu, Mehmet, "Antakya ve Konya Tarihi Kent Dokularının Morfolojik Açıdan Karşılaştırılması", Uluslararası Insan Bilimleri Dergisi, Cilt:6, Sayı:2, 2009, ss.334-347.

Lagarias, Apostolos, "Fractal Analysis of the Urbanization at the Outskirts of the City: Models, Measurement and Explanation", Cybergeo (European Journal of Geography), 2007, s.n.y. (Url: https://cybergeo.revues.org/8902\#toct201n4, erişim tarihi:21.10.2018)

Lorenz, E. Wolfgang, "Fractal Geometry of Architecture: Implementation of the BoxCounting Method in a CAD-Software", 2009, ss.8.

Mandelbrot, B. Benoit, "The Fractal Geometry of Nature”, New York, 1977, ss.498.

McAdams, A. Michael, "Fractal Analysis And The Urban Morphology Of A City In A Developing Country: A Case Study Of Istanbul", Marmara Coğrafya Dergisi, İstanbul, Ocak 2007, Sayı:15, ss.149-172.

Oestreicher, Christian, "A History of Chaos Theory", Dialogues in Clinical Neuroscience, Vol:9, No:3, 2007, ss. 279-289.

Ostwald, J.Michael; Ediz, Özgür, "Measuring Form, Ornament and Materiality in Sinan's Kılıç Ali Paşa Mosque: An Analysis Using Fractal Dimension", Nexus Network Journal, 2014, s.n.y.

Tannier, Cecile; Pumain, Denise, "Fractals in Urban Geography: A Theoretical Outline and An Empirical Example", Cybergeo (European Journal of Geography), 2005, s.n.y. (Url: http://cybergeo.revues.org/3275?lang=en\#tocfrom2n10, erişim tarihi:15.11.2018)

Tekeli, İlhan, "Bursa'nın Tarihinde Üç Ayrı Dönüşüm Dönemi”, 11. Uluslararası Yapı Yaşam Kongresi, Osmanlı Devletinin Kuruluşunun 700. Yıldönümünde Bursa ve Yöresi, Bursa, 6-8 Mayıs 1999, ss. 7-28.

TMMOB Şehir Plancıları Odası (ŞPO) Bursa Şubesi, "Bursa Kent Raporu", Bursa 2009, ss.110.

TÜİK (Türkiye İstatistik Kurumu), www.tuik.gov.tr

Yaygın, Muzaffer Ali, "Kent Dokusundaki Mekansal Değişimin Morfolojik Boyutta Incelenmesi", Selçuk Üniversitesi FBE, Şehircilik Anabilim Dalı, YI. Tezi, 2016, ss.174. 
Kent Dokusu Morfolojik Değişiminin Fraktal Geometri Aracılığıyla Hesaplanması: Bursa Örneği Fractal Geometry Analysis of Urban Tissue Morphological Change: The Case Study of Bursa

Url1:http://www.tdk.gov.tr/index.php?option=com bts\&arama=kelime\&guid=TDK.GTS.

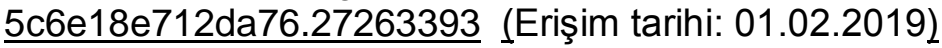

Url2: https://teknosab.com.tr/tr/sayfa/22/38/1/teknosab-hakkinda.html (Erişim tarihi: 20.03.2019)

Url3: http://www.bursa.com/wiki/Odunluk Oduncuk (Erişim tarihi: 09.01.2019)

Url4: http://www.bursa.com/wiki/Millet Mahallesi (Erişim tarihi: 09.01.2019)

Url5:http://sehirmedya.com/bursa-bolge/bursanin-yukselen-degeri-millet-mahallesi/ (Erişim tarihi: 12.03.2019)

Url6: http://www.bursa.com/wiki/Yunuseli Biladiyunus (Erişim tarihi: 09.01.2019)

Url7: http://www.bursa.com/wiki/Balat Koyu (Erişim tarihi: 09.01.2019)

Url8: http://www.bursadakultur.org/niluferin tarihi.htm (Erişim tarihi: 09.01.2019)

Url9: http://www.bursa.com/wiki/Ertugrul Cayirkoy (Erişim tarihi: 09.01.2019)

Url10: http://www.bursa.com/wiki/Ozluce Inesi (Erişim tarihi: 09.01.2019)

Url11: http://www.bursa.com/wiki/Demirci Mahallesi (Erişim tarihi: 09.01.2019)

Url12: http://www.bursa.com/wiki/Kayapa Nilufer (Erişim tarihi: 09.01.2019)

Url13:http://www.bursa.com/wiki/Hasanaga Kizilcikli (Erişim tarihi: 09.01.2019)

Url14: http://www.kestel.bel.tr/belediye/1/tarihce (Erişim tarihi: 09.01.2019) 